\title{
Świadomość czy algorytm? Ludzkie maszyny jako emanacje Frankensteina Mary Shelley w naukach kognitywnych oraz tekstach kultury
}

\begin{abstract}
Saja Krystian, Świadomość czy algorytm? Ludzkie maszyny jako emanacje Frankensteina Mary Shelley w naukach kognitywnych oraz tekstach kultury [Consciousness or Algorithm? Human Machines as Emanations of Mary Shelley's Frankenstein in Cognitive Science and Cultural Texts]. „Przestrzenie Teorii” 33. Poznań 2020, Adam Mickiewicz University Press, pp. 321-352. ISSN 1644-6763. DOI 10.14746/pt.2020.33.16.

Mary Shelley's Frankenstein is without doubt a popular science-fiction novel, which has inspired many generations of artists and creators in popular culture and mass culture. It has also become an inspiration for scientific studies in the field of robotics and cybernetics. Modern cognitive sciences are looking for the perfect pattern that will allow artificial intelligence to be achieved. An important problem for scientists was the lack of full knowledge about consciousness. We are able to recreate the structure of the human body in a machine, but we are not able to fully simulate the neural processes that would create human consciousness. This problem is perfectly illustrated by cultural works, including literature and cinematography. We see in them both the emanations of the motifs contained in Shelley's novel and the realization of scientific hypotheses that shape our image of a conscious, thinking machine.
\end{abstract}

KEYWORDS: literature studies, film studies, cognitive science, consciousness, artificial intelligence, robotics

Friedrich Wilhelm Joseph von Schelling twierdził, że umysł jest szczytowym osiagnięciem natury. Nasze myśli tworzą niepodzielną jedność z uniwersum (przestrzenią materii oraz ducha) ${ }^{1}$. Jesteśmy przecież częścią organizmu Wszechświata, podzielonego na mniejsze jednostki funkcjonalne ${ }^{2}$. W XVIII wieku sądzono, że odkryto zasady, według których funkcjonuje natura wraz z jej mechanizmem poznawczym. Usiłowano wyznaczyć uniwersalny schemat, z pomocą którego rozwiąże się wszystkie zagadki uniwersum, łącznie z istotą człowieczeństwa. Wraz z rozwojem idei mechanistycznej „na człowieka poczęto patrzeć jak na swoisty układ fizyczny, którego za-

${ }^{1}$ Zob. F.W.J. Schelling, Von der Weltseele, eine Hypothese der höheren Physik zur Erklârung des allgemeinen Organismus, [w:] H.A.M. Snelders, Inorganic Natural Sciences 1797-1840: An Introductory Survey, „Studies in Romanticism” 1972, 11, s. 193-215.

${ }^{2}$ Zob. M. Tegmark, Nasz matematyczny Wszechświat. W poszukiwaniu prawdziwej natury rzeczywistości, przeł. B. Bieniuk, E.L. Łokas, Warszawa 2015. 
gadka zostanie rozwiązana, gdy ktoś ułoży odpowiednie równanie"3. Problem w tym, że poznanie samej maszyny nie da odpowiedzi na wszystkie pytania. Należy sięgnać w głąb świadomości, a jej istota do dziś pozostaje największą zagadka ludzkości ${ }^{4}$. Obecnie jesteśmy w stanie imitować zasadnicze funkcje biologiczno-fizyczne organizmu, przenosząc ich działanie na maszyny. Potrafimy między innymi odtwarzać biologiczny mechanizm dźwigni, przekładni oraz pomp, celem zbudowania skomplikowanych protez, sztucznych organów oraz kompletnych kopii ludzkiego ciała. Poznajemy również zasady funkcjonowania procesów poznawczych człowieka, dzięki czemu tworzymy ich komputerowe symulacje oraz wpisujemy je w maszy$n e^{5}$. Na podstawie zaprogramowanych algorytmów automaty znakomicie naśladują nasz sposób bycia, przez co wydają się ludzkie ${ }^{6}$. Niestety nie jest to sztuczna inteligencja ${ }^{7}$. Dopóki nie ustalimy, czym jest świadomość, maszyny pozostaną niedoskonałą imitacją człowieka. Od pokoleń staramy się osiagnąć tzw. efekt Frankensteina, polegajacy na pobudzeniu do życia tego, co martwe. Innymi słowy usiłujemy nadać psychologiczną formę materii nieożywionej oraz sprawić, aby miała ona świadomość. Powyższym zagadnieniom poświęcony jest niniejszy artykuł. Jest on podzielony na dwie zasadnicze części. Pierwsza dotyczy teoretycznych rozważań nad natura świadomości, inteligencji oraz abstrakcji ludzkiej, osadzonej w kontekście powieści Mary Shelley Frankenstein. Druga odnosi się do realizacji przyjętych założeń w tekstach kultury.

${ }^{3}$ E. Kochanowska, Romantyczna literatura wobec nauki. Henryk Ofterdingen Novalisa $i$ Genezis z ducha Stowackiego, Wrocław 2002, s. 31.

${ }^{4}$ Zob. D.C. Dennett, Świadomość, przeł. E. Stokłosa, Kraków 2016.

${ }^{5}$ Zajmuje się tym jedna z subdyscyplin nauk kognitywnych zwana sztuczną inteligencją (AI - Artifical Inteligence). Kognitywistyka bada mózg jako system, w którym zachodzi proces przepływu oraz przetwarzania informacji. To interdyscyplinarny kompleks badawczy, w którego skład wchodzą następujące dyscypliny: psychologia poznawcza, psychosemantyka, filozofia umysłu, lingwistyka kognitywna, matematyka, teoria sztucznej inteligencji, neuronauka itp. (zob. U. Żegleń, Filozofia umystu, Toruń 2007, s. 48-49). Jednym z podstawowych zadań kognitywistyki jest doprowadzenie do integracji danych uzyskanych z wybranych nauk szczegółowych oraz stworzenie spójnej teorii umysłu (zob. J. Woleński, Jaka jest kognitywistyka każdy (?) widzi, [w:] Metodologiczne i teoretyczne problemy kognitywistyki, red. J. Woleński, A. Dąbrowski, Kraków 2014, s. 22-24).

${ }^{6}$ Nie chodzi tu wyłącznie o robotykę. Przynajmniej częściowo na symulacji postępowania ludzkiego oparte są funkcje komputerów osobistych (PC), począwszy od przycisku „start”, a skończywszy na algorytmach programowania. Oprogramowania komputerowe są instynktowne. Odwołuja się do zasad ludzkiego poznania, np. poprzez kod kulturowy (system znaków).

${ }^{7}$ Zdaniem Johna Searle'a oraz Stevana Harnada symulacja zjawiska nie jest tym samym, co jego powielenie (J.R. Searle, Umyst, mózg i nauka, przeł. J. Bobryk, Warszawa 1995; S. Harnad, Minds, Machines and Searle, „Journal of Experimental and Theoretical Artificial Intelligence" 1989, nr 1, s. 5-25). 
Twórcy literatury oraz kinematografii XX i XXI wieku (w szczególności dzieł fantastycznonaukowych) niejednokrotnie posługują się pojęciem świadomości. W kulturze popularnej odnajdujemy ponadto szereg motywów odwołujących się do związanego ze świadomością problemu sztucznej inteligencji. Dostrzegamy w niej również liczne inspiracje powieścią Shelley, za sprawą postaci monstrum, w którym upatruje się prototypu współczesnego cyborga ${ }^{8}$. Autorka powieści kieruje uwagę czytelnika na dwa fundamentalne pytania: czy istnieja jakiekolwiek granice dla ludzkiego umysłu oraz w jakich okolicznościach należy mówić o człowieczeństwie? Spróbuję udzielić odpowiedzi na powyższe pytania, odwołując się do nauk kognitywnych oraz dzieł kultury popularnej.

W proponowanym ujęciu człowiek, zgodnie z nurtem posthumnistyki oraz transhumanistyki, wielokrotnie przekraczać będzie granice swoich biologicznych możliwości, stając się tworem ludzko-maszynowym oraz niby-ludzkim ${ }^{9}$. Jak słusznie stwierdza Grażyna Gajewska: „W epoce postbiologicznej ludzkie ciało podlega demontażowi, fragmentaryzacji, technologizacji i zatraca nienaruszalny charakter, przestaje być nietykalna, organiczna całością" ${ }^{10}$. Rozważanie kwestii ingerencji w ludzkie ciało, w tym przede wszystkim mechanicznej, jest dziś na porządku dziennym. Przykłady tego typu hybrydyzacji zostana zaprezentowane w niniejszej pracy. W swoich rozważaniach przytoczę także najbardziej przydatną dla poruszanych zagadnień koncepcję świadomości oraz wyjaśnię pojęcia sztucznej inteligencji. Uzyskanie możliwości „zbudowania” przez człowieka świadomej istoty należy do kluczowych przejawów zainteresowania Frankensteinem. Nie jest przy tym konieczne, aby miała ona ciało biologiczne. Istnieją liczne dowody naukowe mówiące, że nośnik świadomości nie ma żadnego znaczenia. Być może w niedalekiej przyszłości będziemy w stanie porzucić ciało biologiczne, które bywa postrzegane jako zbędny balast na drodze do ludzkiej doskonałości ${ }^{11}$.

Kluczem do zrozumienia fenomenu świadomości jest idealne odtworzenie procesów myślowych, wraz z ich fundamentem biologicznym. Problem w tym, że musi się tam znaleźć miejsce na „boską cząstkę”, której nie jesteśmy w stanie wyeliminować ${ }^{12}$. Staje się ona nieuchwytnym elementem naszego istnienia, który powinien zostać przeniesiony na mechanizmy ma-

${ }^{8}$ Zob. G. Gajewska, Arcy-nie-ludzkie. Przez science fiction do antropologii cyborgów, Poznań 2010, s. 25.

${ }^{9}$ Zob. M. Błaszczak, Dramatyczne twory „niby-ludzkie”, [w:] Człowiek w relacji do zwierzat, roślin i maszyn w kulturze, t. 2, Od humanizmu do posthumanizmu, red. J. Tymieniecka-Suchanek, Katowice 2014, s. 250-265.

${ }^{10}$ G. Gajewska, dz. cyt., s. 127.

${ }^{11}$ Tego samego zdania są twórcy kultury cyberpunk, poruszający kwestię doskonalenia ludzkiego ciała, dzięki zaawansowanej technologii (por. G. Gajewska, dz. cyt., s. 182-183).

${ }^{12}$ Problem ten wyjaśnię w dalszej części rozważań. 
szyn, celem uzyskania prawdziwej AI. Wobec powyższego w drugiej części artykułu sporo uwagi poświęcę ciałom mechanicznym. Rozważę kwestię czterech typów symulacji: robota, androida, cyborga oraz programu komputerowego, pod kątem możliwości zaistnienia w nich świadomości. Zastanowię się również nad tym, co łączy je z monstrum Frankensteina. Na początku rozważań przytoczę kilka faktów na temat powieści Shelley, istotnych z punktu widzenia poruszanych zagadnień.

\section{Współczesny Prometeusz}

Dziewiętnastowieczny Frankenstein, czyli wspótczesny Prometeusz bywa uważany za pierwsza powieść science fiction $\mathrm{w}$ historii literatury ${ }^{13}$. Koncepcja książki zrodziła się w willi Diodati nad Jeziorem Genewskim 16 czerwca $1816 \mathrm{roku}^{14}$. Niezmiernie istotna w powieści jest postać Wiktora Frankensteina, protoplasty szalonego naukowca, którego nazywano współczesnym Prometeuszem ${ }^{15}$. Główny bohater jest „wprawdzie skrajnym, lecz jednak wyznawcą oświeceniowego ideału rozumu, który może sięgnąć wszędzie, dzięki logice i empirii”'16. Wiktor, bluźnierczo nazywający siebie stwórca, po osiagniętym triumfie nad materią odrzuca własne dzieło ${ }^{17}$. Jest człowiekiem próżnym, pełnym samolubnych ambicji, które nie niosą z sobą nic istotnego dla dobra ogółu. „Mimo wszystkich cierpień, czyniących z niego istnego męczennika, on jest tu w rezultacie winnym i głównym oskarżonym" - zaznacza Marek Wydmuch ${ }^{18}$. Z kolei Gajewska zauważa, że Shelley „co prawda uśmierciła Frankensteina za jego «grzechy», lecz jednocześnie przedstawiła go jako bohatera skłonnego do autorefleksji, świadomego nadużyć swej naukowej władzy i wykazującego skruchę oraz żal za swe czyny" ${ }^{19}$. Wiktor pokutuje za przekroczenie kulturowego tabu nienaruszalności ciała ludzkiego. Złożony z połączonych na nowo fragmentów ludzkich ciał Potwór ma problem z ustaleniem własnego „Ja”. Przed identycznym dylematem staje jego stwórca. Problem ten stał się uniwersalnym zagadnieniem oraz

${ }^{13}$ Zob. B.W. Aldiss, O pochodzeniu gatunków: Mary Shelley, [w:] M.W. Shelley, Frankenstein, przeł. H. Goldmann, Poznań 1989.

${ }^{14}$ Odbyło się wówczas spotkania towarzyskie Shelleyów (mężem pisarki był Percy Bysshe Shelley) z lordem Byronem oraz Johnem Polidorim. Ten ostatni jest autorem opowiadania Wampir (1819), które stało się inspiracją dla Brama Stokera do napisania Draculi (1897).

${ }^{15}$ M. Wydmuch, Gra ze strachem. Fantastyka grozy, Warszawa 1975, s. 80.

${ }^{16}$ R. Nawrocki, Zmierzch bezpieczeństwa oświeceniowych paradygmatów i jutrzenka stereotypu popkultury: gotycyzm i preromantyzm, „Świat i Słowo. Filologia, Nauki Społeczne, Filozofia, Teologia" 2013, 2 (21), s. 87.

${ }^{17}$ Por. M. Wydmuch, dz. cyt., s. 78.

${ }_{18}$ Tamże, s. 80.

${ }^{19}$ G. Gajewska, dz. cyt., s. 127. 
przedmiotem sporów współczesnej antropologii i psychologii. Przerodził się w konflikt natury etycznej, w którym porusza się kwestię ewentualnego dążenia maszyn do upodmiotowienia ${ }^{20}$.

Wiele z późniejszych utworów literackich, bazujących na tym fundamencie, opisuje postać człowieka, który co prawda posługuje się nauka, lecz nie przewiduje konsekwencji własnych czynów. Wśród nich do istotniejszych należy nowela Roberta Louisa Stevensona Doktor Jekyll i pan Hyde (1886) ${ }^{21}$. Jekyll to ceniony londyński lekarz, który pod wpływem eliksiru potrafi przeistaczać się w Mr Hyde'a, ucieleśnienie zła. Wychodzi na jaw podwójna osobowość doktora oraz jego alter ego, które ma być obecne w każdym z nas. Jak stwierdza Wydmuch: „oddzielił Stevenson zły pierwiastek w jaźni człowieka od dobrego, tworząc w ten sposób dwie osobne indywidualności, z których każda jest egzemplarzem krańcowym i na swój sposób doskonałym"². Ta druga, ukryta osobowość Jekylla dopuszcza się licznych wykroczeń oraz zbrodni. Działa wbrew obowiązujaccym normom społecznym, obyczajowym oraz prawnym. Jest złem w czystej postaci. Potwór Frankensteina nie rodzi się okrutnym ani złym ${ }^{23}$. Pozostaje otwartą księga, nadpisywaną nie przez troskliwego ojca, lecz ludzki los. Obowiązkiem Wiktora było „dać swemu Adamowi nazwę, pierwszą iskrę świadomości, pomóc oswoić świat. Ale bóg - uciekł”24. Monstrum nabiera doświadczenia, uczy się oraz poznaje świat pełen niesprawiedliwości, wpadając w pułapkę tzw. stereotypów prześladowczych ${ }^{25}$. „Doświadczenia pouczaja go, że od ludzi spodziewać się może tylko panicznego lęku, odrazy i wrogości” zauważa Wydmuch ${ }^{26}$. Nie ma w tym nic dziwnego. Jak stwierdza Gajewska:

Monstrum stworzone z trupów wzbudza tak wielkie obrzydzenie i strach w bogobojnych ludziach, gdyż jako postać powstała ze zmarłych ciał (zmartwychwstała), może być traktowana jako antychryst przychodzacy, by zburzyć boski porządek i przejąć władzę nad światem ${ }^{27}$.

Dopuszcza się zabójstwa w gniewie, gdy prośba o stworzenie dla niego towarzyszki zostaje odrzucona przez Wiktora ${ }^{28}$. Frankenstein odmawia w obawie, że szkaradne potomstwo Potwora obdarzone nadludzką siłą zdołałoby zagrozić ludzkości.

20 Tamże, s. 164.

${ }^{21}$ R.L. Stevenson, Strange Case of Dr Jekyll and Mr Hyde, London 1886.

${ }^{22}$ M. Wydmuch, dz. cyt., s. 88.

${ }^{23}$ Por. A. Gemra, Od gotycyzmu do horroru. Wilkołak, wampir i monstrum Frankensteina w wybranych utworach, Wrocław 2008, s. 269.

${ }^{24}$ Tamże, s. 268.

${ }^{25}$ Zob. R. Girard, Kozioł ofiarny, przeł. M. Goszczyńska, Łódź 1991.

${ }^{26}$ M. Wydmuch, dz. cyt., s. 78.

${ }^{27}$ G. Gajewska, dz. cyt., s. 123.

${ }^{28}$ M. Wydmuch, dz. cyt., s. 78. 


\section{Demon industrializacji}

Na społeczeństwo dziewiętnastowiecznej Europy, współczesnej dla pisarki, znaczący wpływ wywierała industrializacja. Mówiono wówczas o tzw. „mrocznych fabrykach szatańskich”, które zdominowały życie w miastach przemysłowych. Powszechnym zjawiskiem stał się nieuzasadniony logicznie strach przed technologia. Był on traktowany jak naturalna reakcja organizmu na coś nieracjonalnego. Technofobia, czyli racjonalność oraz irracjonalność strachu przed maszynami, a także wpadanie w panikę przed wszystkim, co techniczne, była zjawiskiem znanym już pod koniec XVIII wieku ${ }^{29}$. W początkowym okresie rewolucji przemysłowej powstał w Anglii radykalny ruch społeczny niszczycieli maszyn. „Luddyści, rekrutujący się z robotników angielskich i chałupników końca XVIII wieku i początku XIX wieku, niszczyli maszyny i urządzenia przemysłowe, upatrując w nich przyczyn niskich płac i groźby bezrobocia" ${ }^{30}$. Gdy do powszechnego użytku weszły szybkie jak na tamte czasy parowozy, ludzkość ogarnął paniczny lęk przed „demonem kolei żelaznej" ${ }^{31}$. Podobny problem pojawił się w momencie, gdy bracia Montgolfier odbyli pierwszy załogowy lot balonem 19 września 1783 roku. Obawy przeniosły się wówczas w stronę maszyn latających.

W polskiej literaturze odnajdujemy liczne przykłady takiego stanu rzeczy. W 1856 roku jeden z prekursorów polskiej literatury fantastycznonaukowej - Teodor Tripplin, wydaje książkę Maskarada w obłokach, czyli podróż napowietrzna na Morze Pótnocne ${ }^{32}$. W pierwszym tomie opisano podróż nowym wynalazkiem - balonem. W dziele Tripplina został uwzględniony opis nienaturalnego strachu, spowodowanego zaobserwowaniem zejścia balonu z obłoków. Innym przykładem lęku przed maszynami jest zbiór nowel fantastycznych Stefana Grabińskiego, zatytułowany Demon ruchu $(1919)^{33}$. Sa to opowieści grozy, osnute na tematyce kolejowej. W nowelach Grabiński dokonuje antropomorfizacji lokomotywy, która rozmawia z człowiekiem, może umrzeć oraz powrócić do żywych niczym demon lub wampir. W ten sposób antropomorfizowana technologia zaczyna zastępować świat nadprzyrodzony. „Technika była więc postrzegana jako coś agresywnego zarówno wobec człowieka, jak i transcendencji, a technicyzacja - jako napaść

${ }_{29}$ Zob. W. Duch, Fascynujacy świat komputerów, Poznań 1997.

${ }^{30}$ M. Szpunar, Technofobia versus technofilia-technologia i jej miejsce we wspótczesnym świecie, [w:] Problemy społeczne w grze politycznej, red. J. Królikowska, Warszawa 2006, s. 372.

${ }^{31}$ Giosue Carducci w utworze Hymn do szatana (1863) zaprezentował parowóz jako dyszącą bestię. Maszyna to potwór, samonapędzająca się bestia, która dąży do programowego celu.

${ }^{32}$ T. Tripplin, Maskarada w obłokach, czyli podróż napowietrzna na Morze Pótnocne, Wilno 1856.

${ }^{33}$ S. Grabiński, Demon ruchu, Warszawa-Kraków 1919. 
na kulturę, duszę człowieka, świat przyrody" - stwierdza Rafał Ilnicki ${ }^{34}$. Wraz z industrializacją obserwowano wzrost potęgi nauki, w tym przeświadczenia o posiadaniu pełnej kontroli nad naturalnymi zjawiskami przyrody. Odchodzono przy tym od alchemii na rzecz racjonalnych nauk ścisłych.

\section{Wiek nauki i eksperymenty z elektrycznością}

Pomimo faktu, że autorka Frankensteina w niewielkim stopniu orientowała się w naukach ścisłych, powieść zawiera szereg nawiązań do dziewiętnastowiecznych badań naukowych ${ }^{35}$. Odwołuje się między innymi do odkrycia tajników krążenia krwi, doświadczeń ówczesnych chemików czy też licznych, mniej lub bardziej naukowych, eksperymentów z elektrycznością ${ }^{36}$. Jeden z ówczesnych - Adam Walker, przekonywał, że istnieje związek między elektrycznościa a życiem ${ }^{37}$. Wykorzystała to autorka powieści, piszacc o ,iskrze” wskrzeszajacej Potwora. W czasach Shelley organizowano publiczne pokazy, w trakcie których stymulowano ludzkie zwłoki elektrycznością (pokazy tego rodzaju zapoczątkował w 1804 roku Giovanni Aldini). Wykłady, kursy anatomii, a także liczne eksperymenty oraz sekcje zwłok wymagały podjęcia pewnych niemoralnych praktyk, w postaci wykradania zwłok z cmentarzy (między rokiem 1800 a 1810 ginęło ich ponad tysiąc rocznie), a nawet mordowania biedaków w celu sprzedaży ich ciał lokalnym chirurgom $^{38}$. Proceder ten jest obecny w powieści Shelley, z zaznaczeniem, że braki w obrębie ciał ludzkich Wiktor zastępował częściami zwierzęcymi, czyniąc z Potwora wyjątkowa, ludzko-zwierzęca hybrydę ${ }^{39}$. Jak zauważa Wydmuch:

${ }^{34}$ R. Ilnicki, Bóg cyborgów. Technika i transcendencja, Poznań 2011, s. 18.

${ }^{35}$ Por. M. Wydmuch, dz. cyt., s. 79.

${ }^{36}$ Krążenie krwi odkrył William Harvey. Jego pracę na ten temat opublikowano w 1628 roku. Ostatecznie badania nad układem krążenia zawdzięczamy Marcello Malpighiemu, który w 1661 roku opisał naczynia włosowate, dzięki wprowadzeniu do badań naukowych mikroskopu (zob. J. Kubicki, Historia największych odkryć anatomicznych ludzkiego ciała, „Puls Uczelni” 2015, (9) 1, s. 42-43).

${ }^{37}$ Zob. F. James, J. Field, Frankenstein and the Spark of Being, „History Today” 1994, 449 , s. $47-53$.

${ }^{38}$ J. Turney, Ślady Frankensteina. Nauka, genetyka i kultura masowa, przeł. M. Wiśniewska, Warszawa 2001, s. 44-41.

${ }^{39}$ A. Gemra, dz. cyt., s. 268. Podobnymi hybrydami, a więc bytami stworzonymi z połaczonych ze sobą elementów, których nie sposób rozdzielić do czystej, autonomicznej postaci, będą później cyborgi. Cyborg jest mieszanym bytem: człowiekiem i robotem jednocześnie. Jak słusznie stwierdza Ilnicki: „Współcześnie cyborgizacja jest postrzegana jako zagrożenie potwornościa. Hybryda nie jest jednak tożsama z monstrum. Choć każde monstrum jest hybryda, to nie każda hybryda jest monstrum" (R. Ilnicki, dz. cyt., s. 18-19). 
W „ponurą noc listopadową" w pracowni Frankensteina powołany zostaje do życia twór, którego ciało (znów o nadludzkich wymiarach) złożone jest z elementów organizmów umarłych, z kości i ścięgien zbieranych po cmentarzach i kostnicach ${ }^{40}$.

Już w XVI wieku przyjęła się tradycja poznawania ciała poprzez rozbieranie go na części. Tak wyłoniła się tzw. kultura sekcji jako sposob zdobywania informacji o ludzkim ciele ${ }^{41}$. Wiktor rozczłonkowywał ciała zmarłych, po czym zszywał z nich monstrualna postać istoty, która była nad wyraz ludzka. Odczuwała lek, ból, strach, poniżenie, rozpacz oraz gniew. Był to odrażajacy, lecz w pełni świadomy człowiek.

Ważny wpływ na kształt Frankensteina miał mit grecki o Prometeuszu, a także opowieść o golemie ${ }^{42}$. Ten ostatni miał być istotą bez duszy, utworzona z gliny na kształt ludzki, ręką człowieka ${ }^{43}$. Stworzenie golema wiąże się z powtarzaniem procesu bożej kreacji. Dzieło ludzkie nie jest jednak doskonałe. Jest tworem nieukończonym, potencjałem materii oraz bezkształtną masa ${ }^{44}$. Nie ma również duszy. Frankenstein wyznacza zmianę w podejściu do tej tematyki. Oto człowiek stwarza żywa, ukształtowana i świadomą istotę. Wiktor nie odwołuje się do wsparcia bóstwa ani żadnych innych sił nadprzyrodzonych, lecz do prawideł nauki. Golem w znaczeniu potocznym pozostaje symbolem bezdusznego automatu, robota lub głupca ${ }^{45}$. Innymi słowy jest realizacją idei sztucznego człowieka. Akt stworzenia golema jest ,analogiczny do współczesnych koncepcji cyborgizacji, które różnią się od niego jedynie stopniem zaawansowania technologicznego. Cyborg to zatem ostatni znany etap transformacji Golema” - zauważa Monika Błaszczak ${ }^{46}$.

${ }^{40}$ M. Wydmuch, dz. cyt., s. 78.

${ }^{41}$ J. Turney, dz. cyt., s. 41.

${ }^{42}$ Istnieje jeszcze jedno źródło inspiracji, opowieści o homunkulusie, czyli karle lub małym człowieczku, którego próbowano stworzyć w średniowieczu w sposób sztuczny (zob. M. Wydmuch, dz. cyt., s. 79).

${ }^{43}$ Opis stworzenia golema został zawarty w dramacie Halpera Lejwika Golem (H. Lejwik, Golem. Dramat w ośmiu obrazach, przeł. O. Mincer, Warszawa 2017). Szczegółowe rozważania na temat tej postaci (w kontekście poruszanych tu zagadnień) odnaleźć można w książce Grażyny Gajewskiej Arcy-nie-ludzkie (s. 108-120) oraz w książce M. Radkowskiej-Walkowicz, Od Golema do Terminatora. Wizerunki sztucznego człowieka w kulturze, Warszawa 2008.

${ }^{44}$ Por. M. Błaszczak, Ptynność - od Heraklita do Baumana, „Przestrzenie Teorii” 2019, 31, s. 127.

${ }^{45}$ Golem, [w:] W. Kopaliński, Stownik wyrazów obcych i zwrotów obcojęzycznych z almanachem, Warszawa 2000, s. 195.

${ }^{46}$ M. Błaszczak, dz. cyt., s. 128. 


\section{Ciało ludzkie - mechanizm maszyn}

Kluczowe znaczenie dla interpretacji powieści, a także jego późniejszych emanacji, mają tezy mechanistyczne. Dzięki powoli kształtującej się filozofii materialistycznej w wyobraźni autorów znalazło się miejsce dla człowieka z krwi i kości, który stawał się „nowym bogiem”. Jego udział w stworzeniu był dużo większy niż we wcześniejszych historiach. Opisywani w literaturze bohaterowie rzeczywiście zaczęli tworzyć żywe istoty. Alternatywną opcją było i nadal jest zbudowanie automatu. Już w czasach antycznych Haron z Aleksandrii konstruował mechaniczne zabawki przypominajace ludzi, napędzane wodą oraz para ${ }^{47}$. Prawdziwy rozkwit automaty przechodziły w XVII i XVIII wieku. Znakomitym przykładem takiego stanu rzeczy może być tzw. Mechaniczny Turek, czyli Turek grajacy w szachy. To osiemnastowieczna mistyfikacja, której autorem był Wolfgang von Kempelen ${ }^{48}$. Inne automaty, nazywane niekiedy pierwszymi androidami, tworzył szwajcarski zegarmistrz Pierre Jaquet-Droz (1721-1790). Jego Pisarz - lalka przedstawiająca kilkuletniego chłopca - mogła zapisywać na papierze dowolne, wprowadzone wcześniej do mechanizmu zdania. Oprócz Pisarza powstał także równie udany Rysownik oraz Pianista. Znany jest również Flecista oraz Mechaniczna kaczka Jacques'a de Vaucansona. Wraz z postępem w rzemiosłach technicznych zaczęto konstruować coraz doskonalsze maszyny, mniej lub bardziej zbliżone do człowieka. Temat automatów niemal natychmiast został przeniesiony na grunt literacki. Pisywali o nich między innymi Jean Paul, Edgar Allan Poe, Ernst Theodor Amadeus Hoffmann, Juliusz Verne, Ambrose Bierce oraz Ludwik Niemojewski ${ }^{49}$.

Również w filozoficznych dyskusjach renesansu koncentrowano uwagę na mechanizmach. Kartezjusz w swojej mechanistycznej koncepcji uważał, że zasadniczo wszystkie organizmy można traktować jak automaty. W Rozprawie o metodzie czytamy, że różnica między ciałem żywym a umarłym jest analogiczna do tej między zegarem nakręconym, a nie nakręconym ${ }^{50}$. Filozof traktował mechanizm ludzkiego organizmu jak całość złożoną z części, które muszą ze sobą współgrać, aby sprawnie wykonywać rozmaite czynności.

${ }^{47}$ Tamże, s. 129. Zob. również: G. Gajewska, dz. cyt., s. 149.

${ }^{48}$ Pierwszy raz zaprezentowano Turka w 1769 roku. Rzekomo miała być to genialna maszyna, rozgrywająca po mistrzowsku partię szachów. W rzeczywistości był to utalentowany szachista ukryty wewnątrz maszyny oraz sterujący ruchami kukły (zob. W. Litmanowicz, J. Giżycki, Szachy od A do Z, t. 1, Warszawa 1986, s. 420-422).

${ }^{49}$ Por. M. Wydmuch, dz. cyt., s. 81.

${ }^{50}$ Zob. Kartezjusz (R. Descartes), Rozprawa o metodzie wtaściwego kierowania rozumem i poszukiwania prawdy w naukach, przeł. T. Żeleński-Boy, Kraków 2002. 
Uczeń Kartezjusza Julien Offray de La Mettrie neguje całkowicie różnicę między materią ożywioną a nieożywiona, a także między ciałem a duszą ${ }^{51}$. W myśl monizmu La Mettriego wszelkie własności życia obecne sa w uniwersalnej materii, lecz aby się ujawnić, potrzebują właściwej struktury ${ }^{52}$. Co więcej, nie ma przeszkód, aby z materii nieożywionej uzyskać ożywiona, pod warunkiem, że zdołamy rozpędzić jej mechanizm. Człowiek u La Mettriego jest traktowany jako układ wzajemnie napędzających się sprężyn, przekładni oraz dźwigni. Innymi słowy ludzkie ciało, podobne do zegara, porusza się dzięki mechanizmowi współdziałających ze sobą elementów. Wolna wola, utożsamiana z dusza, nie odgrywa tu żadnej roli ${ }^{53}$. Zdaniem La Mettriego pobudliwość mięśni ma swoje źródło w ich miąższu, czyli sprężynie (materii białkowej). Wszystkie ruchy życiowe dokonują się za ich sprawa $^{54}$. Powyższej tezie zawierzył Wiktor, tworząc z martwej tkanki istotę żywa, opartą na odtworzonym układzie szkieletowym oraz ruchu sprężyn mięśniowych, pobudzonych do działania dzięki elektryczności. Ludzkie ciało rzeczywiście przypomina maszynę. Jest doskonale zorganizowane, zestrojone oraz w pełni funkcjonalne ${ }^{55}$.

Twierdzenia La Mettriego sprawdzają się znakomicie we współczesnej teorii maszyn oraz mechanizmów. Jest to nauka o technicznej realizacji ruchu, obejmująca zagadnienia struktury oraz kinematyki, a także dynamiki mechanizmów płaskich i przestrzennych ${ }^{56}$. Człowiek, jako istota strukturalna, wykonuje szereg ruchów kinematycznych oraz dynamicznych. Maszyna to urządzenie stanowiące układ połączonych ze sobą ciał, o ściśle określonym ruchu, którego zadaniem jest wykonanie pracy użytecznej lub przekształcenie energii. Owe maszyny dzielimy w zależności od uzyskiwanego efektu. Wyróżniamy maszyny energetyczne, transportowe, technologiczne, kontrolne i sterujacce, informatyczne oraz cybernetyczne ${ }^{57}$. Ludzkie ciało to maszyneria łącząca te kategorie. Mechanizmy funkcjonuja w nim dzięki ogniwom czynnym (napędowym) oraz biernym (pędzonym). Z kolei mechanizm to układ połączonych ze sobą ciał (ogniw), mogących

${ }^{51}$ Zob. J.O. de La Mettrie, Człowiek - maszyna, przeł. S. Rudniański, Warszawa 1984.

${ }^{52}$ Tamże, s. 91.

${ }^{53}$ Zdaniem filozofa wolna wola nie ma wpływu na pewną grupę zachowań, zaś stan duszy zależy od stanu ciała. Dusza to wrażliwa część materialna mózgu, którą można uznać za główną sprężynę całego mechanizmu (por. J.O. de La Mettrie, dz. cyt., s. 73-74).

${ }_{54}$ Tamże, s. 68.

${ }^{55}$ Zob. C.A. Ville, Biologia, przeł. H. Bielewska, T. Bilewicz-Pawińska, H. Gutowska, W. Kilarski, A. Makarewicz, W. Prażmo, Z. Stromenger, Warszawa 1978; R.D. Jurd, Biologia zwierzat, przeł. A. Lesicki, K. Ziemnicki, Warszawa 2007.

${ }^{56}$ J. Wawrzecki, Teoria maszyn i mechanizmów. Wstęp do teorii mechanizmów przestrzennych, Łódź 2008, s. 15.

${ }^{57}$ Tamże, s. 16. 
wykonywać ściśle określony ruch względny, którego zasadniczym zadaniem jest przeniesienie ruchu. Uzyskuje on przy tym efekt energetyczny, wykonując pracę użyteczną lub też przekształcająca energię. Proces ten następuje od źródła energii do organu wykonawczego ${ }^{58}$. Powyższe założenia są bezpośrednio przekładalne na zasady funkcjonowania ludzkiego ciała. Jesteśmy przecież skomplikowanymi, biologiczno-fizycznymi maszynami, o strukturze składającej się z dźwigni, łożysk, sworzni, przekładni oraz pomp. W przedstawionych powyżej tezach brakuje zasadniczego elementu, jakim jest ludzka świadomość. La Mettrie całkowicie pomija ten problem. Świadomość utożsamiana z dusza jest dla niego stanem ciała oraz jedną ze sprężyn biologicznego zegara.

Istotnym protoplastą powieści Shelley jest opowiadanie wspomnianego już Hoffmanna Piaskun z 1816 roku. Młody bohater o imieniu Nataniel zakochuje się w automacie imitujacym kobietę o imieniu Olimpia. W Piaskunie czytamy o udanej próbie stworzenia sztucznego człowieka - androida, na zasadach wskazanych w dziele La Mettriego (budowa kobiety oparta jest na mechanizmie zegarowym). Jest to zapowiedź późniejszych dzieł kultury popularnej o podobnej tematyce, a także nauk kognitywnych, których głównym zadaniem jest doprowadzenie do powstania sztucznej inteligencji. Luźną adaptacją opowiadania jest film w reżyserii Alexa Garlanda Ex Machina z 2015 roku, w którym młody informatyk Caleb zakochuje się w Avie, androidzie wyposażonym w sztuczną inteligencje ${ }^{59}$. Niestety, marzenie o budowie idealnych maszyn niknie w obliczu kilku fundamentalnych problemów natury fizycznej oraz mentalnej. Kluczowym ograniczeniem jest brak pełnej wiedzy o świadomości. Nie bez znaczenia jest również, w sposób oczywisty powiązany ze świadomościa, problem możliwości uzyskania przez maszynę ludzkiego poziomu abstrakcji.

\section{Problem pierwszy: świadomość}

Do dziś największą tajemnicą stworzenia pozostaje fenomen świadomości. Stanowi on główną barierę na drodze do uzyskania inteligentnych maszyn. Pod pojęciem sztucznej inteligencji rozumiem zdolność do rozwiazywania problemów sposobami wzorowanymi na naturalnych działaniach i procesach poznawczych człowieka za pomoca symulujących je programów komputerowych ${ }^{60}$.

\footnotetext{
${ }^{58}$ Tamże, s. 15.

${ }^{59}$ Ex Machina [film], scen. i reż. A. Garland, 2015.

${ }^{60}$ J. Jagielski, Inżynieria wiedzy, Zielona Góra 2005, s. 15.
} 
U podstaw sztucznej inteligencji legło konstruowanie modeli układu nerwowego człowieka, a w szczególności mózgu. Dysponujemy coraz większą wiedzą o działaniu mózgu, ale dalej nie w pełni rozumiemy, jak przebiegają procesy myślowe, kojarzeniowe, wnioskowanie, przetwarzanie języka naturalnego, operowanie symbolami, czy też subiektywne wartościowanie. Wszystkie sztuczne systemy - w sposób mniej lub bardziej udany - naśladuja procesy przebiegające w naturze. Ułomność ich wynika zarówno z niekompletnej wiedzy o mechanizmach rzeczywistych, jak i z powodu niedoskonałości technicznych środków realizacji określonych procesów ${ }^{61}$.

Ponieważ otaczająca nas rzeczywistość jest strukturą matematyczna, jesteśmy w stanie przynajmniej obliczeniowo symulować ludzkie zachowania $^{62}$. Nie jest to efekt wystarczajacy dla wygenerowania AI. Głównym celem Artificial Intelligence jest imitowanie przez programy komputerowe zawartości desygnatów, takich jak inteligencja praktyczna, abstrakcyjna oraz społeczna, właściwych dla inteligencji naturalnej ${ }^{63}$. Problem z uzyskaniem AI wynika z niemożliwości dotarcia do źródła wiedzy świadomej. Umiejętność kodowania wiedzy, czyli stosowania jej reprezentacji symbolicznej jest warunkiem powodzenia w rozwiązywaniu problemów w sztucznej inteligencji ${ }^{64}$. Niestety, obok wiedzy prawdziwej może istnieć wiedza fałszywa. Tylko istota świadoma ma dostęp do obu jej typów, rozpoznaje je, a także prawidłowo oraz celowo z nich korzysta, niezależnie od poprawności algorytmu sterującego. Algorytm matematyczny wpisany w maszynę jest w stanie symulować wiedzę uznaną za pewną i niepewna, lecz nie będzie w stanie przewidzieć oraz przeanalizować holistycznie wszystkich możliwych kombinacji, celem podjęcia właściwej decyzji. Uczynić to może jedynie osoba świadoma, o subiektywnym, osobistym punkcie odniesienia oraz rozwiniętym mechanizmie abstrakcji.

Znamy dziś wiele definicji świadomości. Żadna z nich nie jest wystarczająca, zaś ich różnorodność powoduje zamęt poznawczy. Pojęcie to pozostaje niesprecyzowane. Odwołuje się do wielu zjawisk różnej kategorii ${ }^{65}$. Jak traf-

${ }^{61}$ Tamże, s. 17.

${ }^{62}$ Por. D. Chalmers, Świadomy umyst. W poszukiwaniu teorii fundamentalnej, przeł. M. Miłkowski, Warszawa 2010, s. 512.

${ }^{63}$ Inteligencja praktyczna to sprawność w rozwiązywaniu konkretnych zadań, inteligencja abstrakcyjna jest zdolnością do operowania pojęciami i symbolami, inteligencja społeczna to umiejętność zachowania się w grupie (por. J. Jagielski, dz. cyt., s. 14). Inteligencja naturalna „oznacza pewne zdolności poznawcze polegające na sprawnym zdobywaniu i przetwarzaniu wiedzy oraz jej praktycznym wykorzystaniu, które może obejmować zdolność rozumienia, kojarzenia, oceniania, zdolności wynajdowania odpowiednich reakcji na nowe warunki życia i nowe zadania. W ujęciu ewolucjonizmu Herberta Spencera inteligencją jest nieustanne przystosowywanie związków wewnętrznych do warunków zewnętrznych" (J. Jagielski, dz. cyt., s. 14-15).

${ }^{64}$ Por. J. Jagielski, dz. cyt., s. 23. Wykształcono oddzielny dział AI zwany inżynierią wiedzy, który zajmuje się problemem kodowania wiedzy.

${ }^{65}$ Zob. D. Chalmers, dz. cyt., s. 33-41.

$$
\begin{array}{l|l}
\text { Krystian Saja } & 332
\end{array}
$$


nie stwierdzono w International Dictionary of Psychology: „świadomość jest fascynującym, ale nieuchwytnym zjawiskiem: nie sposób powiedzieć, czym jest, co robi, dlaczego wyewoluowała"66. Problem polega między innymi na subiektywnym charakterze przeżyć i stanów intencjonalnych, do których nie mamy dostępu poza własnym „Ja”. Stan umysłu jest świadomy, jeśli odwołuje się do tzw. qualium, czyli jakości danego przeżycia ${ }^{67}$. Powyższe uwagi oscylują wokół odwiecznego problemu umysł-ciało, który jak dotąd nie uzyskał jednoznacznego wyjaśnienia ${ }^{68}$.

Za najciekawszą ze znanych koncepcji świadomości, która usiłuje rozwiązać powyższy problem, uznaję interpretację biologicznego naturalizmu Johna Searle'a. Stany świadomości wraz z ich subiektywna, pierwszoosobową ontologia sa w niej realnymi fenomenami, osadzonymi w realnym świecie $^{69}$. Świadomość jest pierwszoosobowa, ponieważ pozostaje naszą osobistą subiektywnością. Nie da się przeprowadzić eliminacyjnej redukcji świadomości, która dowiodłaby, że jest ona złudzeniem. Nie da się również całkowicie zredukować świadomości do jej neurobiologicznego fundamentu, ponieważ taka trzecioosobowa redukcja gubi pierwszoosobową ontologię. W biologicznym naturalizmie stany świadomości są skutkiem zachodzacych w mózgu procesów neurobiologicznych niższego poziomu ${ }^{70}$. Są również kauzualnie redukowalne do procesów neurobiologicznych. Nie można im przyznać własnego życia. Nie są czymś ponadto względem procesów mózgowych (czynności mentalne są skutkiem procesów mózgowych). Świadomość jest zatem całkowicie opisywalna kauzualnie poprzez zachowanie się neuronów, lecz nie wynika stąd, że jest jedynie zachowaniem neuronów. Można przeprowadzić kauzualną redukcję świadomości do jej neuronowego budulca, ale nie prowadzi to do redukcji ontologicznej. Zredefiniowanie świadomości do terminów trzecioosobowych pozbawi ją sensu, $\mathrm{w}$ tym operacyjnego ${ }^{71}$. Powyższy problem uniemożliwia pełną symulację, jak i odtworzenie procesów świadomościowych w maszynie. Na obecnym poziomie wiedzy nie osiagniemy poznawczego minimum. Zasady fizyczne rządzące procesem świadomościowym oraz ich podłoże biologiczne są dziś dobrze znane. Niestety, w świadomości jest coś więcej, co nieuchronnie zbliża nas do kategorii boga. Nie jesteśmy w stanie znieść filozoficznej bariery kreacjonizmu, z powodu braku możliwości przeprowadzenia ontologicznej redukcji jeden do jednego.

\footnotetext{
${ }^{66}$ Zob. The International Dictionary of Psychology, red. N.S. Sutherfand, New York 1989.

${ }^{67}$ J. Searle, Umyst. Krótkie wprowadzenie, przeł. J. Karłowski, Poznań 2010, s. 138.

${ }^{68}$ Tamże, s. 25-27, 49-86.

${ }^{69}$ Tamże, s. 117.

${ }^{70}$ Tamże.

${ }^{71}$ Tamże, s. 122-134.
} 


\section{Problem drugi: abstrakcja}

Całkowita redukcja umysłu do podłoża biologicznego nie jest możliwa. Powodem takiego stanu rzeczy jest pierwszoosobowa świadomość, a także fakt istnienia sfery abstrakcyjnego opisu rzeczywistości, bardzo często całkowicie oderwanego od kategorii bytu realnego. W mowie potocznej definicji abstrakcji używamy na opisanie czegoś, co jest oderwane od rzeczywistości fizycznej, jest skomplikowane, niezrozumiałe oraz nieopisywalne ${ }^{72}$. W Wielkim słowniku wyrazów obcych $P W N$ pod pojęciem abstrakcji czytamy, że jest to pogląd lub twierdzenie oderwane od rzeczywistości, nieoparte na faktach, wyprowadzone z pewnych z góry przyjętych założeń. To cecha lub relacja odseparowana od konkretnych obiektów ${ }^{73}$. Z kolei abstrahowanie traktowane jest jako proces tworzenia pojęć ogólnych, polegający na wyodrębnieniu cech bądź relacji w konkretnym przedmiocie lub zdarzeniu ${ }^{74}$. Stownik wyrazów obcych wydawnictwa „Europa” przyjmuje natomiast, że abstrakcja jest pojęciem, poglądem lub teorią całkowicie oderwaną od rzeczywistego stanu rzeczy. To coś nierzeczywistego, fikcyjnego, ,zawieszonego” w mentalności człowieka ${ }^{75}$.

Istoty człowieczeństwa poszukuje się dziś w świecie abstrakcji wyższego rzędu. Jest nią umiejętność tworzenia pojęć, zasad oraz znaków niemających żadnego odpowiednika w świecie rzeczywistym. Przykładem mogą być liczby 1, 2, 3, 4, 11 itd., które nie mają fizykalnego odpowiednika (sa jedynie figurami funkcjonalnymi). Abstrakcyjne jest to, co pozostaje elementem czysto mentalnym. To coś całkowicie oderwanego od rzeczywistości fizycznej, co nie może być traktowane jak punkt odniesienia. Byt abstrakcyjny jest częścią świadomości wyższego rzędu, czyli takiej, w której posiadamy samoświadomość siebie, historii i planów na przyszłośćc ${ }^{76}$. Pamiętajmy również, że w języku łacińskim abstraho oznacza odrywać, rozdzielać. Musi to być oderwanie całkowite, w pełni psychologiczne, w przeciwnym bowiem razie pozostaniemy w przestrzeni symbolu, a nie abstraktu. Dopóki nie opuścimy owej przestrzeni oraz nie spojrzymy na matematykę z perspektywy abstrakcyjnej, oderwanej od desygnatu, tak długo „zmysł liczby” pozostanie tym, co dzielimy z naszymi zwierzęcymi przodkami ${ }^{77}$. Abstrakcja jest tym,

${ }^{72}$ M. Grabowski, Podziw i zdumienie w matematyce i fizyce, Warszawa 2009, s. 50.

${ }^{73}$ Wielki stownik wyrazów obcych PWN, red. M. Bańko, Warszawa 2003, s. 5.

${ }^{74}$ Tamże.

${ }^{75}$ Stownik wyrazów obcych, red. I. Kamińska-Szmaj, Wrocław 2001, s. 17.

${ }^{76}$ Zob. G.M. Edelman, Wider than the Sky: The Phenomenal Gift of Consciousness, New Haven 2004.

${ }^{77}$ B. Brożek, M. Hohol, Umyst matematyczny, Kraków 2014, s. 33. 
co definitywnie odróżnia nas od zwierząt ${ }^{78}$. Wiemy dziś, że zwierzęta mają pewien zasób zdolności abstrakcyjnych (np. naczelne) ${ }^{79}$. Domeną czysto ludzka pozostaje umiejętność „odrywania” przedmiotu mentalnego od zjawisk zmysłowych ${ }^{80}$. Tworzymy w ten sposób literaturę, abstrakcyjne obrazy oraz imaginacje. Jak słusznie zauważa Robin Dunbar:

Tu właśnie tkwi różnica pomiędzy nami a naszymi małpimi braćmi - w świecie wyobraźni. Potrafimy sobie wyobrazić, że rzeczy nie musza być takie, jakimi je postrzegamy. Możemy udawać, że przez nasz ogród przemykaja wróżki. Możemy konstruować wymyślne rytuały i wierzenia mające swoja genezę wyłącznie w naszej wyobraźni. Pozostałe zwierzęta tego nie potrafia, nie są bowiem w stanie spojrzeć na rzeczywistość z zewnątrz i zastanowić się, co by było gdyby ${ }^{81}$.

Abstrakcja oraz jej zrozumienie pozwala, przynajmniej częściowo, ominąć problem świadomości. Istnieją dziś maszyny, które dzięki wpisanemu algorytmowi wydają się niemal ludzkie. Symulują one świadome procesy abstrakcji, lecz nadal nie mają świadomości.

Biorąc pod uwagę powyższe rozważania, możemy stwierdzić, że Potwór Frankensteina jest pełnoprawnym człowiekiem w ciele półczłowieka. To istota świadoma, która potrafi posługiwać się abstrakcją wyższego rzędu. Monstrum jest człowiekiem, który - tak jak inni - potrafi rozumować logicznie, planować, a także rozważać za oraz przeciw. Wiemy również, że nauczył się on rozróżniać dobro od zła. Niestety, umiejętność tę nabył poprzez samotne

${ }^{78}$ Tego typu teze przedstawił Darwin w dziele $O$ pochodzeniu człowieka (przeł. S. Panek, Warszawa 1959, s. 80), pisząc: „różnica między umysłem człowieka i wyższych zwierząt, mimo że jest wielka, jest różnicą stopnia, a nie rodzaju. Wrażenia i odczucia, różne uczucia i zdolności, jak miłość, pamięć, zdolność do skupiania uwagi, do rozumowania, ciekawość, naśladownictwo itp., którymi szczyci się człowiek, można stwierdzić $\mathrm{w}$ zalążku, a nawet niekiedy zupełnie dobrze rozwinięte $\mathrm{u}$ niższych zwierząt. [...] Jeśli utrzymuje się, że poczucie własnej osobowości oraz zdolność do tworzenia pojęć abstrakcyjnych itp., są specyficzne dla człowieka, to być może są one wynikiem ubocznym innych wysoko wyspecjalizowanych zdolności umysłowych, stanowiących z kolei główny rezultat stałego używania w wysokim stopniu rozwiniętej mowy".

${ }^{79}$ Zob. B. Brożek, M. Hohol, dz. cyt., s. 14.

${ }^{80}$ Zdaniem Jerzego Bartmińskiego przedmiotem mentalnym jest jednostka podlegajaca definiowaniu „w całym bogactwie jego charakterystyki utrwalonej w językowym obrazie świata. [...] Ten przedmiot mentalny jest projekcja, a nie odbiciem, niezależnie od tego, że zwykle istnieje możliwość porównania go (i stwierdzenia podobieństw) z przedmiotem rzeczywistym, dostępnym doświadczeniu empirycznemu" (N. Lemann, Prototyp i profilowanie przedmiotu mentalnego SMOK $w$ literaturze fantasy, na wybranych przyktadach, [w:] Kognitywizm w poetyce i stylistyce, red. G. Habrajska, J. Ślósarska, Kraków 2006, s. 143-144; J. Bartmiński, Definicja kognitywna jako narzędzie opisu konotacji, [w:] Profilowanie pojęć. Wybór prac, red. J. Bartmiński, Lublin 1993, s. 75-76).

${ }^{81}$ R. Dunbar, Nowa historia ewolucji człowieka, przeł. B. Kucharzyk, Kraków 2014, s. 200. 
zdobywanie doświadczenia od dnia swych narodzin, śladem teorii wychowania Jeana-Jacques'a Rousseau (okazało się to tragiczne w skutkach) ${ }^{82}$. Potwór powstał w laboratorium szalonego naukowca dzięki wykorzystaniu wiedzy naukowej oraz pseudonaukowej, co nie zmienia faktu, że jest on pełnoprawnym człowiekiem.

\section{Emanacje Frankensteina: cybernetyka i robotyka}

Powyższe ustalenia dotyczące motywów zawartych we Frankensteinie, a także związane z nimi rozważania na temat świadomości są obecne w różnych obszarach nauki i kultury. Robotyka oraz cybernetyka, bazując na doświadczeniach kognitywistów, starają się zbudować możliwie najdoskonalszą kopię człowieka. Jeden z nurtów sztucznej inteligencji, nurt bioniczny, czyli silna sztuczna inteligencja zmierza do budowy komputera wyposażonego w procesor myślowy zbliżony do ludzkiego mózgu ${ }^{83}$.

Nurt bioniczny zmierza do poznania funkcji mózgu i ich naśladowania z wykorzystaniem urządzeń technicznych lub substytutów tkanki nerwowej. W ramach tego nurtu prace prowadzone są nad analizą działania neuronów, modelowaniem pojedynczych neuronów i ich współdziałaniem w procesie myślowym ${ }^{84}$.

W szeroko pojętej przestrzeni ludzkiej kreacji dostrzegamy tendencję do powielania powyższych wzorców, przede wszystkim na polu kultury popularnej. Nauka miesza się z tym, co wyimaginowane, budując zaplecze dla dzieł science fiction. Dochodzi również do karnawalizacji wzorców naukowych oraz literackich, w której: „motywy powtarzaja się, ale funkcjonując w nowym kontekście, mają już inne znaczenia, niejednokrotnie zniekształcają też funkcje, jakie pełniły w tradycyjnych kulturach" ${ }^{85}$. Tym samym trudno jednoznacznie stwierdzić, czy kolejne odsłony wcześniejszych wyobrażeń tworzą jakikolwiek kanon. Literatura oraz kinematografia prezentują szereg przykładów zastosowania modeli oraz technik sztucznej inteligencji. Część z nich to rozwiązania autentyczne, inne pozostają czysto abstrakcyjną wariacją twórców. Starają się oni odtworzyć lub poddać obróbce fundamentalne motywy, ukonstytuowane na bazie IA oraz te obecne we Frankensteinie. Poniższe rozważania posłużą zobrazowaniu wskazanych zależności.

\footnotetext{
${ }^{82}$ Por. M. Wydmuch, dz. cyt., s. 80.

83 J. Jagielski, dz. cyt., s. 18.

${ }^{84}$ Tamże.

${ }^{85}$ Zob. G. Gajewska, dz. cyt., s. 90.
} 


\section{Roboty w ludzkim świecie}

Początkowo słowo robot odnosiło się do istot żywych, a mianowicie do sztucznie produkowanej, uproszczonej wersji człowieka przeznaczonej do ciężkiej pracy. Warto wynotować fakt, że w mitologii sumeryjskiej istota ludzka powstała z inicjatywy młodszych i niższych rangą bogów Anunnaki, którzy zbuntowali się przeciwko ciężkiej pracy. Człowiek stał się pomocnikiem bogów, a właściwie ich niewolnikiem. Spadł na niego obowiązek opieki nad siecią kanałów oraz rzek, uprawy roli, budowy świątyń, a także uroczystego obchodzenia dni poświęconym bogom ${ }^{86}$. Dowodzi to faktu, że w bogatej historii ludzkości pragnienie posiadania „niewolnika”, wykonującego za nas pracę, było zjawiskiem powszechnym. Z tego samego powodu budujemy roboty, automaty, maszyny fabryczne oraz komputery. Sa to samoczynne, w całości sztuczne konstrukcje, które mają wykonywać najcięższe oraz najbardziej skomplikowane prace ${ }^{87}$.

Obraz robota powyższego typu odnajdujemy w sztuce „R.U.R.” (Rossumovi Univerzální Roboti) z 1921 roku Karela Čapka ${ }^{88}$. Jest to wizja utopii, w której opisano fabrykę robotów, które pracują dla ludzi, aby stworzyć idylliczne życie bez trudów pracy. Jest to również wczesna zapowiedź Terminatora, ponieważ w pewnym momencie roboty buntują się przeciwko stwórcy ${ }^{89}$. Termin robotyka istnieje za sprawą Isaaca Asimova, który ukuł to pojęcie w swojej noweli science fiction pod tytułem Zabawa w berka $(1942)^{90}$. Jest on również autorem praw robotyki, które brzmią następująco:

1. Robot nie może skrzywdzić człowieka ani przez zaniechanie działania dopuścić, aby człowiek doznał krzywdy.

2. Robot musi być posłuszny rozkazom człowieka, chyba że stoją one w sprzeczności z Pierwszym Prawem.

3. Robot musi chronić sam siebie, jeśli tylko nie stoi to w sprzeczności z Pierwszym lub Drugim Prawem.

Obecnie słowo robot oznacza urządzenie mechaniczne, wykonujące automatycznie określone zadania. Działanie robota może być sterowane przez człowieka, za sprawą wgranego wcześniej programu bądź zbioru ogólnych reguł, przełożonych na działanie robota za pomocą technik sztucznej

${ }^{86}$ Zob. K. Łyczkowska, K. Szarzyńska, Mitologia Mezopotamii, Warszawa 1981, s. 212-214.

${ }^{87}$ Por. G. Gajewska, dz. cyt., s. 148. Problem pojawi się zapewne w momencie uzyskania przez roboty świadomości. Przykład ludzki udowadnia, że każda istota świadoma, wyłączona ze sprawiedliwego systemu społecznych relacji, prędzej czy później zbuntuje się przeciwko niesprawiedliwości.

${ }^{88}$ K. Čapek, R.U. R., Praha 2016.

${ }^{89}$ Według mitologii sumeryjskiej ludzie pracujący dla bogów także dopuścili się buntu, zyskując tym samym prawo do samostanowienia.

${ }^{90}$ I. Asimov, Zabawa w berka, [w:] tegoż: Ja, robot, przeł. Z.A. Królicki, Poznań 2013. 
inteligencji. Co ważne, podstawa funkcjonowania robota jest zazwyczaj energia elektryczna, czerpana z baterii lub łącza kablowego (jest to zgodne z Frankensteinem). Robot nie musi być podobny wizualnie do człowieka. Może mieć odmienną naturę fizyczną. W rozpatrywanej kategorii robotów należy dokonać istotnego dla rozważań podziału na androidy oraz droidy. Dojdziemy wówczas do kilku interesujących wniosków.

\section{Android}

Android to robot humanoid, czyli sztucznie stworzona istota, która kształtem przypomina ludzkie ciało. Tu również mówimy o dwóch typach: o androidzie jako sztucznie wyhodowanym oraz genetycznie zmodyfikowanym człowieku, co jest bezpośrednią emanacją motywu „nowego człowieka” z Frankensteina oraz o robotach mechanicznych ${ }^{91}$. Do powszechnie znanych realizacji androidów filmowych w formie robotów mechanicznych należą np. C-3PO z serii filmów Gwiezdne wojny w reżyserii George'a Lucasa lub też Terminator (T-800, T-1000, T-X) z serii filmów Terminator (1984 i 1991, 2003, 2009, 2015) w reżyserii (kolejno) Jamesa Camerona, Jonathana Mostowa, Josepha McGinty Nichola oraz Alana Taylora. Inne przykłady to Bishop i Ash z filmu Obcy - ósmy pasażer Nostromo (1979) Ridleya Scotta, a także Obcy - decydujace starcie (1986) Jamesa Camerona. Szczególnie interesującym androidem jest również Dawid z filmu A.I. Sztuczna Inteligencja $^{92}$ (2001) Stevena Spielberga.

Pewna grupa wyżej wymienionych robotów wydaje się mieć świadomość ludzka. Należy do nich Dawid. Jest on robotem, chłopcem zdolnym do miłości. To robot rozumny ze wspomaganiem neuronowym, cechujący się „podświadomościa, wewnętrznym światem metafor, intuicji, motywacji samodzielnego rozumowania oraz marzeń" ${ }^{93}$. Nim stworzono Dawida, tzw. mach, czyli robot służebny, nie był w stanie samodzielnie podejmować decyzji. Spełniał wszelkie polecenia stwórcy, uczył się reakcji na ból, lecz

${ }^{91}$ Przykład androida będącego wyhodowaną kopią człowieka dostarcza nam film Łowca androidów w reżyserii Ridleya Scotta (1982), który został już skrupulatnie przeanalizowany w wielu opracowaniach. Innym przykładem może być powieść science fiction Czy androidy śnia o elektrycznych owcach? napisana przez Philipa K. Dicka, wydana po raz pierwszy w 1968. Akcja utworu ma miejsce w 2021 roku w San Francisco (w oryginalnej wersji utworu był to rok 1992). Tematyką powieści jest problem koegzystencji ludzi i androidów oraz typowe dla autora rozważania o sensie człowieczeństwa.

${ }^{92}$ Film jest adaptacją opowiadania Briana Aldissa Supertoys Last All Summer Long z 1969 roku. Ekranizację powieści planował Stanley Kubrick, jednak ówczesna technologia nie pozwalała jeszcze na realizację wymarzonego filmu.

${ }^{93}$ AI, sztuczna inteligencja [film], reż. S. Spielberg, scen. S. Spielberg, I. Watson, 2001. 
interweniował zgodnie z logicznym uzasadnieniem. Był zabawką z sensorami i inteligentnymi obwodami behawioralnymi. Chłopięcy android jest inny. Miłość w chłopcu uruchamia się poprzez procedurę wdrukowania hasłem sekwencji algorytmu. Raz zaprogramowana miłość zostanie w nim na zawsze. Android ten potrafi posługiwać się abstrakcja, lecz nie jest to pełna świadomość. Nie ma wolnej woli. Miłość została zaprogramowana, zatem jest spełnieniem zadań wyznaczonych przez program oraz skutkiem przetwarzania danych. Jak stwierdza Ilnicki: ,przetwarzanie danych nie wystarczy, aby mówić o jakimkolwiek poziomie duchowości w maszynie, jeśli nie uwzględni się sposobu jej funkcjonowania"94.

Bez wątpienia świadomość ma android z filmu Ja, robot (2004) w reżyserii Alexa Proyasa, luźno opartego na zbiorze opowiadań Asimova z 1950 roku o tym samym tytule. Opisuje on świat w roku 2035, w którym roboty pomagają ludziom w codziennym życiu. Następuje jednak przełom, gdy jeden z robotów zostaje oskarżony o zabójstwo swego stwórcy. W filmie padaja bardzo interesujące słowa odnoszące się do świadomości:

Maszyny zawsze miały duszę, przypadkowe elementy kodu, które połączyły się, by wydać nieoczekiwane rozkazy. Te wolne rodniki mogą dać początek wolnej woli, kreatywności, a nawet czemuś, co możemy nazywać duszą. [...] Kiedy schemat percepcji staje się świadomością? Kiedy niezależny system zaczyna szukać prawdy? Kiedy symulacja osobowości staje się kawałkiem cierpiącej duszy ${ }^{95}$

Jest $\mathrm{w}$ tych słowach sporo prawdy, biorąc pod uwagę biologiczny naturalizm Searle'a. Przypadkowe elementy kodu rzeczywiście mogą się okazać droga ku świadomości. Pozostałe z wymienionych androidów są podobne do Golema, niemającego duszy. Mimo zewnętrznego podobieństwa do istoty ludzkiej, sa one martwe w sensie psychologicznym.

Oddzielnym problemem pozostaje kwestia świadomości terminatorów, którym poświęcę więcej uwagi. W filmie Terminator tzw. Skynet, czyli Cyberdyne Systems - wojskowy system obronny, odgrywający rolę głównego filmowego antagonisty, miał uzyskać świadomość, decydując się na zagładę ludzkości. Nie jest to prawdą. Skynet został zaprojektowany tak, aby chronić człowieka przed zagrożeniem zewnętrznym, zgodnie z prawami robotyki. W momencie, gdy gatunek homo sapiens stał się zagrożeniem dla siebie samego, program uznał go za wroga, podejmując jednocześnie decyzję o jego eksterminacji. Złamał przy tym prawo pierwsze. Z cała pewnością było to działanie uzasadnione logiką matematyczna, a nie przypadkową konfiguracją składowych algorytmu. Nie jest to świadomość, lecz wspomniany kod postępowania, który wyznacza najbardziej optymalne rozwiązanie problemu,

${ }^{94}$ R. Ilnicki, dz. cyt., s. 59.

${ }^{95}$ Ja, robot [film], reż. A. Proyas, scen. A. Goldsman, J. Vintar, 2004. 
nie zważając na ludzką empatię, litość czy tzw. zdrowy rozsądek. Mamy tu natomiast wyraźne nawiązanie do Frankensteina: dzieło człowieka wymyka się spod kontroli i występuje przeciwko swemu stwórcy ${ }^{96}$. Ponadto sam Terminator jest maszyną stworzoną przez inną maszynę. Nie wykazuje żadnych cech ludzkich ${ }^{97}$. Wpisuje się doskonale w idee nurtu bionicznego AI, za sprawą posiadania jednostki centralnej, podobnej w działaniu do ludzkiego mózgu. Procesor ten nie był w stanie wytworzyć świadomości, ponieważ nie było to celem Skynetu. Filmowy android to niebezpieczny przybysz z przyszłości, który zagraża dniu teraźniejszemu ${ }^{98}$. Grażyna Gajewska zaznacza, że: „Terminator z mechanicznym uporem trwa przy postanowieniu zabicia kobiety nawet wtedy, gdy jest już pozbawiony kończyn, a część jego obwodów jest przepalona. [...] Postać ta przeraża dlatego, że jest samosterującym automatem"99.

Film Terminator uzmysławia nam, jak silny był dwudziestowieczny strach przed technologią oraz jak bardzo jest on zakorzeniony w ludzkiej świadomości. Opiera się on na pięciu stałych przesłankach, które wymienia Wydmuch. Po pierwsze, od czasów Frankensteina ambicje człowieka do naśladowania dzieła stworzenia uznawane są przez wierzących za czyn grzeszny i godny potępienia. Po drugie, nieufność budzi próba rekonstrukcji procesów naturalnych. Sa one tym straszniejsze, im bardziej nieudolne. Po trzecie, roboty zbyt bardzo odbiegaja wyglądem od istot ludzkich. Sa podzielone na bryły, które symbolizować mają części ciała człowieka. Maja one również nadludzkie możliwości, za sprawą usunięcia biologicznych ograniczeń. Poza tym rzecz udająca uduchowienie jest równie straszna, jak duch udający rzecz. Przerażenie wzbudza połyskujący gładki metal z powłoki robotów, a także jego ukrycie za sztuczna skóra. Po czwarte, automat to potencjalny szaleniec, który - aby osiagnąć wyznaczony mu cel - gotów jest zabić, lub jeśli każe tak logika - więzić człowieka (tak jak w opowieści Jamesa Gunna Uszczęśliwiacze, w której to maszyny umieszczają ludzkość w sztucznym łonie matki, po logicznym przeliczeniu, że tylko tam człowiek był naprawdę szczęśliwy). Jest to nieobliczalność kalkulacji cybernetycznego mózgu, tok elektronowych przeliczeń lub po prostu ślepy automatyzm. Po piąte, roboty miewają zwarcia i awarie, w konsekwencji czego stają się nieobliczalne. Jest to obawa przed spięciem, które z pomocnika może stworzyć mordercę (tak też się stało w Terminatorze) ${ }^{100}$. Konsekwencją powyższych fobii jest przeświadczenie, o którym wspomina Giorgio Agamben, pisząc:

${ }^{96}$ J. Turney, dz. cyt., s. 61.

${ }^{97}$ Sytuacja ulega zmianie dopiero w drugiej części filmu Terminator 2. Dzień sqdu (1991), w której reżyser stara się przedstawić rozważania o filozoficznej tożsamości maszyny.

${ }^{98}$ Por. G. Gajewska, dz. cyt., s. 27.

${ }_{99}$ Tamże.

${ }^{100}$ M. Wydmuch, dz. cyt., s. 82-88. 
„Dzieje ludzkości sprowadzają się zapewne do walki ludzi z urządzeniami będącymi ich wytworem"101. Zacieranie granic między człowiekiem a maszyną rodzi konflikt w postaci uznania przez ludzkość praw do szacunku, wolności i samostanowienia maszyn, o czym - przynajmniej na razie - nie chcemy słyszeć ${ }^{102}$.

Terminator ujawnił kolejny problem - strach przed przyszłościa. W latach osiemdziesiątych bardzo popularne stały się filmy przedstawiające wizje apokaliptyczne brudnej, okrutnej przyszłości. Zaliczamy do nich np. Ucieczkę z Nowego Jorku Johna Carpentera, Mad Max II. Road Warrior George'a Millera (oba z 1981 roku), Ostatnia walka Luca Bessona (1983) oraz Element zbrodni Larsa von Triera (1984) ${ }^{103}$. Cameron odwoływał się również do ciagle żywych lęków związanych z zimną wojną. 23 marca 1983 roku prezydent Stanów Zjednoczonych Ronald Reagan ogłosił zaawansowany program prac nad tzw. Inicjatywą Obrony Strategicznej. Był to system strategicznej obrony przeciwrakietowej krajów NATO przed atakiem balistycznym ze strony Związku Radzieckiego. Zaawansowane platformy wyrzutni rakietowych (a także laserów) miały niszczyć pociski wroga, nim te przekrocza granice ich terytorium ${ }^{104}$. Choć programu nigdy nie udało się zrealizować ze względu na barierę technologiczna, stał się on zapowiedzią współczesnej tarczy antyrakietowej. Tym samym nie dziwi fakt, że po premierze Terminatora utożsamiano SDI ze Skynetem. Filmowy system obrony zniszczył ludzkość przy użyciu światowego arsenału nuklearnego. Wykorzystał rakiety balistyczne, kończąc zimną wojnę tzw. Dniem Sądu. Działał przy tym w pełni logicznie oraz analitycznie (pierwsze uderzenie skierował na Wschód). Film wpisał się doskonale w ówczesny porządek oraz lęki ludzkości. Zapewne przyczyniło się to do wielkiego sukcesu niskobudżetowego filmu z 1984 roku, który w gruncie rzeczy był absolutnym kiczem (w przeciwieństwie do części drugiej) ${ }^{105}$.

Obecnie humanoidalne roboty wyposażone w uczące się systemy SI są na wyciagnięcie ręki. Amerykańska firma Boston Dynamics stworzyła

${ }^{101}$ G. Agamben, Profanacje, przeł. M. Kwaterko, Warszawa 2006, s. 91.

${ }_{102}$ Por. G. Gajewska, dz. cyt., s. 167. W październiku 2017 roku, podczas odbywającego się w Arabii Saudyjskiej forum Future Investment Initiative, nadano po raz pierwszy w historii świata obywatelstwo żeńskiemu androidowi Sophie. Ponieważ androidowi przyznano więcej praw obywatelskich, niż w tym kraju mają kobiety, podniosły się głosy krytyki z tym związane (zob. Robot dostat obywatelstwo Arabii Saudyjskiej. Sophia „ma więcej zagwarantowanych praw niz kobiety" < https://www.forbes.pl/technologie/humanoidalny-robot-z-obywatelstwem-arabii-saudyjskiej/04wfw7n> [dostęp: 1.03.2020]).

${ }^{103}$ Por. 1001 filmów, które musisz zobaczyć, red. S.J. Schneider, Warszawa 2004, s. 708.

${ }^{104}$ Stownik terminów z zakresu bezpieczeństwa narodowego, Akademia Obrony Narodowej, Warszawa 2008, s. 54.

${ }^{105}$ Por. 1001 filmów, które musisz zobaczyć..., s. 708. 
humanoidalnego robota Atlasa, który uzyskał zdolność do sprawnego poruszania się na dwóch kończynach w naturalnym terenie ${ }^{106}$. Kluczem do człowieczeństwa jest jednak świadomość oraz inteligencja. Robot humanoidalny powinien pozyskać umiejętność nauki, zaś ta polega na treningu systemu SI, poprzez dostarczanie jak największych ilości danych do odtworzonej sieci neuronowej. Sieć neuronów to olbrzymi magazyn ludzkiej pamięci. Zapisujemy na nim wrażenia percepcyjne, sądy, uczucia, poglądy, a także ulotne chwile, o ile staną się dla nas istotne ${ }^{107}$. Odbywa się to poprzez tzw. reprezentacje neuronowe - swoistego rodzaju mentalne kopie wrażeń zmysłowych ${ }^{108}$. Umiejętność tego rodzaju miał Terminator T-800, model 101 w drugiej części filmu Terminator 2. Dzień sqdu (1991). W jednej ze scen android zapytany o umiejętność nauki, odpowiedział: „Moja jednostka centralna to sieć neuronowa, mogę się uczyć, im więcej stykam się z ludźmi, tym więcej się uczę"109.

Filmy Camerona prezentują urzeczywistnioną wizję końca dwudziestego wieku o zaawansowanych technicznie androidach, które z założenia mają służyć ludzkości. Sa także ponura wizją skutków ludzkiej obsesji postępu, zmierzajacej do stworzenia nowego Potwora Frankensteina. Program, który urzeczywistnił się pod postacią maszyny mającej metalowy endoszkielet oraz ludzką inteligencję, podobnie jak Potwór, poznał się na ludzkiej próżności i dla ratowania świata postanowił go zniszczyć.

\section{Droid}

Droidy to skomplikowane technicznie roboty, wyposażone w system imitujący sztuczną inteligencję. Funkcjonują one przede wszystkim w uniwersum świata możliwego Gwiezdnych wojen. Jednym z nich jest robot naprawczy R2-D2. Droidy znane z filmów Lucasa nie mają świadomości. Potrafią rozwiązać wiele problemów logicznych, lecz nie wykazują cech ludzkich. Interesujący jest natomiast przypadek animowanego droida $\mathrm{z}$ oska-

${ }^{106}$ Zob. Atlas. The World's Most Dynamic Humanoid Robot, <https://www.bostondynamics.com/atlas> [dostęp: 1.02.2020].

${ }^{107}$ Zob. M. Spitzer, Jak uczy się mózg?, przeł. M. Guzowska-Dąbrowska, Warszawa 2007.

${ }^{108}$ Reprezentacje to trwałe ślady w naszych umysłach po ulotnych wrażeniach z otaczającego nas świata. To wewnętrzne kopie określonych cech charakterystycznych i struktur otoczenia, przekazywanych z zewnątrz w formie bodźców. Są one zapisywane na neuronie lub grupie neuronów, zgromadzonych w modułach (zob. M. Spitzer, dz. cyt., s. 22, 69, 79).

${ }^{109}$ Terminator 2. Dzień sqdu [film], reż. J. Cameron, scen. J. Cameron, W. Wisher, 1991. W reżyserskiej wersji filmu ludzcy bohaterowie otwierają czaszkę Terminatora, uruchamiając podzespoły odpowiedzialne za naukę. Robot nie stał się przez to człowiekiem, ale uzyskał umiejętność samodzielnej oceny zdarzeń oraz pogłębionej nauki. 
rowej animacji Andrew Stantona Wall-e z 2008 roku. Bez wątpienia ma on świadomość ludzka. Wniosek ten wysuwam na podstawie analizy strony mentalnej droida, który przeżywa prawdziwe emocje, w tym smutek oraz miłość do innego robota.

Do grupy droidów możemy także zaliczyć robota z filmu Krótkie spięcie (1986) w reżyserii Johna Badhama. Tak zwany Johnny 5 zyskał świadomość za sprawą uderzenia pioruna, co w sposób bezpośredni przywołuje na myśl eksperyment Wiktora Frankensteina. Świadomy i obdarzony wolna wolą robot w jednej ze scen filmu podkreśla, że jest istotą żywą. W świetle najnowszych ustaleń wiemy, że nie ma konieczności, aby życie było oparte na węglu ${ }^{110}$. Do głównych cech istot żywych należy posiadanie zorganizowanej struktury, dostosowanie wewnętrznego zachowania do krótkoterminowych zmian w środowisku, realizowanie obu powyższych funkcji dzięki pozyskiwaniu energii z otoczenia, reagowanie na bodźce zewnętrzne, na przykład przez przemieszczanie się w kierunku pożywienia, wzrost, lecz taki, który nie polega jedynie na gromadzeniu coraz większej ilości materii bez jej wykorzystywania, rozmnażanie się oraz przystosowanie się do długookresowych zmian zachodzących w środowisku ${ }^{111}$. Układ mający większość $\mathrm{z}$ wymienionych cech może zostać uznany za istotę żywą ${ }^{112}$. Jak twierdzi Claude Alvin Villee - w większości są to właściwości umowne. Ukazują nam funkcjonalny obraz istoty, którą z powodzeniem może być wskazany powyżej droid, a w sposób oczywisty jest nim Potwór Frankensteina ${ }^{113}$. W przeważającej części opowieści o robotach mówi się jak o maszynach niemających świadomości. Działają na podstawie algorytmu matematycznego, o którym wspomniałem we wcześniejszych rozważaniach.

\section{Cyborgi}

Do całkowicie odmiennej grupy należą cyborgi. Cyborg (od ang. cybernetic organism - organizm cybernetyczny) to „pół człowiek, pół maszyna; organizm, którego niektóre procesy życiowe są wspomagane lub całkowicie realizowane

${ }^{110}$ Zob. R. Dawkins, Wehikut przeżycia, przeł. J. i M. Jannaszowie, [w:] Trzecia kultura, red. J. Brockman, Warszawa 1996, s. 107.

${ }^{111}$ I. Stewart, Matematyka życia, przeł. B. Bieniuk, E.L. Łokas, Warszawa 2014; R. Fortey, Życie. Nieautoryzowana biografia. Historia naturalna pierwszych czterech miliardów lat życia na Ziemi, przeł. M. Machalski, K. Sabath, Warszawa 1999, s. 392.

112 Tamże.

${ }^{113}$ Materia nieożywiona może wykazywać pewne cechy istot żywych, np. kryształy moga „rosnaçc”, krople tłuszczu unoszące się w mieszaninie gliceryny i alkoholu mogą poruszać się na podobieństwo ameby itp. (zob. C.A. Ville, dz. cyt., s. 46). 
przez urządzenia techniczne"114. Pojęcie to po raz pierwszy pojawiło się w artykule Manfreda Clynesa i Nathana Kline'a, opublikowanym w czasopiśmie Astronautics w 1960 roku $^{115}$. Możliwość integracji człowieka z maszyną miała stać się podstawą dla przyszłej eksploracji kosmosu. Człowiek miał być zdolny do życia w „każdym środowisku, jakie tylko sobie wybierze” ${ }^{116}$. Nowoczesna technologia pozwala udoskonalić naturalne zdolności człowieka, tak w sferze fizycznej, jak i mentalnej. Umożliwia zbudowanie nowoczesnej biologiczno-mechanicznej hybrydy, zdolnej do nadludzkich czynów. W koncepcji autorów artykułu jest sporo racji. Za sprawa wynalezienia w pełni wartościowego skafandra kosmicznego eksploracja kosmosu stała się możliwa ${ }^{117}$.

W dyskursie akademickim pojęcie cyborga pojawiło się w 1985 roku, za sprawą artykułu Donny Haraway. Czytamy w nim, że: „Cyborg jest organizmem cybernetycznym, hybrydą maszyny i organizmu, wytworem rzeczywistości społecznej i fikcji”"118. Biolożka zauważa, że obecnie „wszyscy jesteśmy chimerami, wymyślonymi i sfabrykowanymi hybrydami maszyny i organizmu, słowem, jesteśmy cyborgami”119. Jest w tym sporo racji. W dalszej części tekstu Haraway przekonuje nas, że prędzej czy później nastapi proces legitymizacji i normalizacji podejścia do cyborgów, ponieważ dochodzi dziś do zatarcia granic między tym, co sztuczne, a tym, co naturalne. Stopień zaawansowania technologicznego ludzkości doprowadza do ciagłego udoskonalania człowieka oraz „naprawiania” w nim tego, co ulega zużyciu (np. dzięki rozrusznikowi serca).

Termin cyborg bardzo szybko trafił do książek, filmów, a także komiksów fantastycznonaukowych. Jego występowanie jest elementem charakterystycznym literatury nurtu cyberpunk, czyli odmiany fantastyki naukowej, skupiającej się na ukazywaniu negatywnych konsekwencji funkcjonowania ludzi w otoczeniu zaawansowanej technologii ${ }^{120}$. Jest to kolejny objaw lęku przed nowoczesną techniką. Jak zauważa Gajewska: „Cyborgi w kulturze po-

${ }^{114}$ Cyborg [hasło], Wielka encyklopedia PWN, red. J. Wojnowski, Warszawa 2002, t. 6, s. 228. Jeżeli w definicji cyborga poprzestanie się na kryterium „połączenia człowieka i maszyny", to za cyborga uznać należy każdego człowieka mającego implant, będący urządzeniem mechanicznym lub elektronicznym (np. rozrusznik serca). Dlatego termin stosowany jest raczej w odniesieniu do ludzi, których układ nerwowy połączony jest z elementami elektronicznymi (np. komputerem) metodą inwazyjną i ewentualnie także z urządzeniami mechanicznymi. Komputer oraz układ nerwowy powinny wzajemnie na siebie oddziaływać.

${ }^{115}$ M.E. Clynes, N.S. Kline, Cyborgs and Space, „Astronautics” 1960, wrzesień, s. 26-76.

116 Tamże, s. 29.

${ }^{117}$ Prace nad pierwszym skafandrem kosmicznym rozpoczęły się już w latach trzydziestych XX wieku.

${ }^{118}$ D. Haraway, Manifest cyborgów: nauka, technika i feminizm socjalistycznych lat osiemdziesiatych, przeł. S. Królak, E. Majewska, „Przegląd Filozoficzno-Literacki” 2003, nr 1, s. 49.

119 Tamże, s. 50.

${ }^{120}$ Przykładem tego typu literatury są opowiadania Williama Gibsona Neuromancer z 1984 roku lub Johnny Mnemonic z roku 1981. 
pularnej prezentujące najczęściej bardzo wysoki stopień ludzko-technicznej imersji i introjekcji, przygotowują nas na powitanie monstrualnej przyszłości"121. Przyszłość ta to nowoczesna technologia, która tworząc z człowieka nowe monstrum - człowieka-maszynę, staje się przyczyną nowych fobii. Możliwości fizyczne tak bardzo hybrydycznej istoty są dla nas tajemnica. Na jej wizji bazuje współczesna kultura popularna, która straszy nas niepewną przyszłościa:

Jeśli za Derridą przyjmiemy, że monstrum jest tym, które zjawia się po raz pierwszy, jest jeszcze niepoznane i nienazwane, to jasne staje się, dlaczego potwór Wiktora Frankensteina - jako normatywny precedens i prototyp cyborga - nie ma imienia. Monstrum to jest anormalne, obsceniczne, gdyż nie zostało jeszcze zidentyfikowane, oswojone, zaakceptowane. [...] Odległa przyszłość jest jak monstrualny przybysz, po którym nie wiemy, czego się spodziewać122.

Interesującym przykładem realizacji postaci cyborga w kulturze popularnej jest komiksowa postać Iron Mana amerykańskiego wydawnictwa Marvel Comics. Komiks zatytułowany właśnie Iron Man doczekał się ekranizacji pod tym samym tytułem w roku 2008 (reżyseria: Jon Favreau). Bohaterem filmu jest naukowiec Anthony Edward „Tony” Stark. Stworzył on serię cybernetycznych zbroi, czyli wyjątkowych kombinezonów, wyposażonych w najnowocześniejsze technologie (przede wszystkim wojskowe). Wspomagając swoje ciało dodatkowym szkieletem mechanicznym w postaci zbroi, Stark staje się superbohaterem ${ }^{123}$. Podobne kombinezony istnieja $\mathrm{w}$ świecie rzeczywistym, lecz nie maja tak rozwiniętych funkcji. Jednym z nich jest egzoszkielet HULC, wspomagający pracę nóg ${ }^{124}$. Został stworzony przez firmę Berkeley Bionics oraz rozwinięty przez Lockheed Martin ${ }^{125}$. Dzięki systemowi HULC żołnierz będzie w stanie bez większego wysiłku nieść na sobie sam szkielet oraz ładunek o wadze 90 kilogramów. Koncern Lockheed opracował także inny system, nazwany Fortis. Jest to lekki, 12-kilogramowy egzoszkielet odwzorowujący ruchy ludzkiego ciała, umożliwiający przenoszenie ciężkich przedmiotów bez najmniejszego wysiłku. Amerykańska marynarka wdraża właśnie wersję militarną Fortisa, o nazwie Onyx, która ma trafić do armii w bieżącym roku ${ }^{126}$.

${ }^{121}$ G. Gajewska, dz. cyt., s. 25.

122 Tamże.

${ }^{123}$ Koncept takiego pancerza pojawił się po raz pierwszy w opowiadaniu Starship Troopers z 1959 roku, autorstwa Roberta Anson Heinleina (por. G. Gajewska, dz. cyt., s. 29-30).

${ }^{124}$ Nazwa system nawiązuje do innej postaci komiksowej, HULCK-a.

${ }^{125}$ Zob. Lockheed Martin's HULC(TM) Robotic Exoskeleton Enters Biomechanical Testing At U.S. Army Natick Soldier Systems Center, <https://news.lockheedmartin.com/ 2011-06-30-Lockheed-Martins-HULC-TM-Robotic-Exoskeleton-Enters-Biomechanical-Testing-at-U-S-Army-Natick-Soldier-Systems-Center> [dostęp: 1.02.2020].

${ }_{126}$ Zob. Strength To Go The Distance, <https://www.lockheedmartin.com/en-us/products/ exoskeleton-technologies/military.html> [dostęp: 1.02.2020]. 
Pancerzem zbliżonym do dzieła Starka jest egzoszkielet korporacji Raytheon, XOS 2, wspomagający pełen zakres ruchów ${ }^{127}$. Warto również wspomnieć o zbroi projektowanej na zlecenie Amerykańskiego Dowództwa Operacji Specjalnych. Naszpikowany elektronika kombinezon, z wbudowanym egzoszkieletem oraz pancerzem, o nazwie TALOS, stworzyli między innymi naukowcy Politechniki Warszawskiej. Głównym elementem jest tu płynna substancja kuloodporna, wypełniajaca pancerz oraz zmieniajacca stan skupienia z płynnego $\mathrm{w}$ stały $\mathrm{w}$ kilka milisekund ${ }^{128}$. Wskazane przykłady wyprodukowanych zbroi Iron Mana służyć mają przede wszystkim wojsku. Stanowią bezpośrednią emanację komiksowej wizji Marvela.

Innym przykładem cyborga jest RoboCop, czyli uwięziony w sztucznym ciele policjant. Gdy funkcjonariusz Alex Murphy zginął na służbie, został przywrócony do życia jako cyborg, którego zadaniem było zwalczanie przestępczości. Film RoboCop z 1987 roku w reżyserii Paula Verhoevena to nic innego jak bezpośrednie naśladownictwo powieści Shelley, choć bezpośrednią inspiracją dla reżysera stał się inny film o robotach Łowca androidów Ridleya Scotta. Cyborg powstaje w korporacyjnym laboratorium z wykorzystaniem najnowszych osiagnięć cybernetyki oraz robotyki. Ciało policjanta zawiera jedynie szczątkowe części ludzkie. Pozostałą część stanowi konstrukcja z tytanu, pokrytego Kevlarem (przypominam, że potwór zawierał w sobie części zwierzęce) ${ }^{129}$. Cyborgami zawsze są ludzie wspomagani przez maszynę. Innymi słowy są to ludzie w maszynie, którzy dzięki mechanice uzyskali nadludzką siłę oraz umiejętności. Udoskonalenie ludzkiego ciała leżało u podstaw projektu Wiktora Frankensteina. Jego Potwór był niezwykle silny fizycznie oraz osiagnął ponadprzeciętne rozmiary ciała. Cyborgi mają świadomość, choć bywa, że postępują zgodnie z instrukcją logiczno-matematyczną. Program z dyrektywami został wpisany w pancerz RoboCopa, choć ostatecznie udało mu się przełamać ograniczenie systemowe. Murphy, wbrew ograniczeniom, poszukuje utraconej osobowości, prowadząc dochodzenie na temat własnej śmierci.

${ }^{127}$ Zob. Raytheon XOS 2 Exoskeleton, Second-Generation Robotics Suit, <https://www. army-technology.com/projects/raytheon-xos-2-exoskeleton-us/> [dostęp: 1.02.2020].

${ }^{128}$ Zob. Kombinezon „superżotnierza” staje się rzeczywistościa, <https://tech.wp.pl/kombinezon-superzolnierza-staje-sie-rzeczywistoscia-usa-juz-niebawem-uzbroi-nim-swoje-wojsko-6256653151475329a> [dostęp: 1.02.2020].

${ }^{129}$ Kevlar - rodzaj włókien poliamidowych wynaleziony w 1965 roku w laboratoriach DuPonta. Używa się go do produkcji kamizelek kuloodpornych, hełmów i trampolin, w wewnętrznych powłokach nart, rakietach tenisowych, kajakach i częściach pancerza lotniskowców, a także do wzmacnia kabli światłowodowych, obuwia lub odzieży (zob. J. Godzimirski, Lotnicze materiaty konstrukcyjne, Warszawa 2008, s. 154-155; Wytrzymaty Kevlar, czyli włókna aramidowe, <https://materialyinzynierskie.pl/wytrzymaly-kevlar-wlokna-aramidowe> [dostęp: 5.02.2020]). 
O wiele więcej szczegółów anatomicznych RoboCopa dostarcza remake filmu z 2014 roku. Dowiadujemy się w nim, że cyborg śni, ma wspomnienia, odczuwa emocje, utrzymując ciagłe połączenie z częściowo odtworzonym mózgiem oraz rdzeniem kręgowym. Murphy ma ponadto własne płuca oraz lewą dłoń. Pozostaje w nim element ludzki. Jest człowiekiem-maszyna. Świadomość jest tu utożsamiana z przetwarzaniem danych. Owo przetwarzanie nie pozwala cyborgowi przełamać granic elementu ludzkiego, strachu, instynktu, uprzedzeń, współczucia, które kolidują z systemem. Według twórców filmu zasada funkcjonowania RoboCopa jest następująca: „Software ocenia zagrożenie, przesyła dane do mózgu. Mózg je przetwarza i podejmuje decyzje w oparciu o emocje i zdolności poznawcze. Mózg przekazuje to modułowi AI, a komputery wieńczą dzieło"130. Jego emocjonalność zostaje częściowo ograniczona. Zyskuje szybszy software i mocniejszy hardware, aby cyborg mógł idealnie spełniać swoje obowiązki131. W sytuacji bojowej uruchamia się program i o wszystkim decyduje maszyna, zaś Alex ma wówczas wygenerowana iluzję wolnej woli. Na co dzień to człowiek ma kontrolę nad maszyną. W filmie zaznacza się również, że społeczeństwo nie akceptuje obecności robotów między ludźmi. Korporacja stworzyła androidy, które miały patrolować ulice miasta. Nie mając zaufania do robotów lub zwyczajnie odczuwając przed nimi lęk, obywatele Detroit oczekiwali czegoś innego, produktu mającego sumienie, człowieka w maszynie, który będzie okazywać uczucia. Właśnie dlatego korporacja OmniCorp, której pracownicy są odzwierciedleniem szalonego naukowca z Frankensteina, decyduje się na stworzenie człowieka-maszyny.

Do powszechnie znanych cyborgów filmowych należy również Darth Vader ze wspomnianych kilkukrotnie Gwiezdnych wojen. Vader, a tak naprawdę Anakin Skywalker, po przejściu na tzw. ciemną stronę Mocy oraz dotkliwym okaleczeniu ciała, wspomaga swoje czynności życiowe specjalnym kombinezonem. Jest to kolejny przykład odrodzenia się istoty ludzkiej oraz nabycia przez nią ponadgatunkowych umiejętności za sprawą udoskonalenia tkanki biologicznej.

\section{Oprogramowanie}

Do ostatniej grupy rozpatrywanych emanacji należą programy komputerowe, czyli sekwencja symboli zwana algorytmami, opisująca realizowanie

${ }^{130}$ RoboCop [film], reż. J. Padilha, scen. J. Zetumer, 2014.

${ }^{131}$ Software to oprogramowanie, ogół informacji w postaci zestawu instrukcji, zaimplementowanych interfejsów i zintegrowanych danych przeznaczonych dla komputera do realizacji wyznaczonych celów. Celem oprogramowania jest przetwarzanie danych w wyznaczonym przez twórcę zakresie. Hardware to sam sprzęt komputerowy, materialna część komputera. 
obliczeń zgodnie z pewnymi regułami zwanymi językiem programowania ${ }^{132}$. Reguły te oparte są na dwóch elementach: kodzie i danych, przy czym kod inicjuje przetworzenie danych. Przykładem filmowego programu jest oczywiście Skynet z Terminatora, lecz o wiele ciekawszym przypadkiem wydaje się Matrix z filmu braci Wachowskich z 1999 roku o tym samym tytule ${ }^{133}$. Prawdopodobnie jest to program świadomy. Pewnym jest, że osoby w nim przebywające, za sprawa specjalnych portów są istotami świadomymi, np. haker komputerowy Neo, który jest człowiekiem z krwi i kości. Mózg Neo został podłączony do systemu komputerowego, co umożliwia dokonywanie w nim świadomych korekt.

Do nieświadomych programów wpływających na życie ludzkie należy również tzw. Czerwona Królowa, komputer korporacji Umbrella ze słynnej serii gier oraz filmów zatytułowanych Resident Evil $(2002)^{134}$. Korporacja jest największym dostawca technologii komputerowych i produktów medycznych. Gdy w trakcie nieudanego eksperymentu niebezpieczny wirus dostaje się do szybu wentylacyjnego, zgodnie z protokołem bezpieczeństwa Czerwona Królowa zamyka wszystkie wyjścia laboratorium, zabijając przy tym pracowników korporacji. Komputer ten nie rozważa za i przeciw. Nie ma również zaprogramowanego współczucia czy też empatii, stąd taka, a nie inna decyzja programu. Czerwona Królowa nie ma świadomości, lecz doskonale ją imituje, podając się między innymi za dziecko. Podobny schemat zastosowano w filmie Terminator. Ocalenie (2009) ${ }^{135}$. Widzimy w nim upostaciowiony Skynet, który podaje się za kobietę.

\section{Zakończenie}

Obecnie na gruncie badań na temat ludzkich maszyn pojawił się nowy kierunek, wywodzący się z tzw. trzeciej kultury. Mowa tu o biorobotyce, zajmującej się konstruowaniem, wytwarzaniem oraz eksploatacją biomechanicznych oraz elektronicznych urządzeń, służących do modyfikowania ciała i poszerzania jego możliwości. Wskazuje ona istotny problem, dotyczący tzw. socjalizacji maszyn oraz sposobów przystosowywania ludzi do współistnienia z nowymi technologiami oraz maszynami ${ }^{136}$. Biorobotyka tym samym

${ }^{132}$ M. Ben-Ari, Understanding Programming Languages, Chichester 1996.

${ }^{133}$ Matrix [film], scen. i reż. L. Wachowski, L. Wachowski, 1999.

${ }^{134}$ Evil [film], scen. i reż. P.W.S. Anderson, 2002.

${ }^{135}$ Terminator. Ocalenie [film], reż. J. McGinty Nichol, scen. J. Brancato, M. Ferris, 2009.

${ }^{136}$ Zob. W stronę trzeciej kultury. Koegzystencja sztuki, nauki i technologii, red. R.W. Kluszczyński, Warszawa 2011; Sztuka i kultura robotów. Bill Vorn i jego histeryczne maszyny, red. R.W. Kluszczyński, B. Vorn, N. Gingras, D. Moulon, J. Walewska, P. Celiński, Gdańsk 2014; Nervoplastica. Guy Ben-Ary „Sztuka bio-robotyczna i jej konteksty kulturowe”, red. R.W. Kluszczyński, Gdańsk 2015. 
może się okazać niezwykle pomocna w interpretacji wyżej wymienionych maszyn oraz ich „oswajaniu” w ludzkiej świadomości.

Podsumowując powyższe rozważania, należy odpowiedzieć na dwa postawione wcześniej pytania, dotyczące możliwości ludzkiego umysłu oraz istoty człowieczeństwa. Po pierwsze, wydaje się, że możliwości ludzkiego umysłu są nieograniczone. Krępuje nas jedynie jakość posiadanej wiedzy o świecie, poziom rozwoju pierwszoosobowej abstrakcji utożsamianej z wyobraźnią i kreatywnością oraz zdolności poznawcze. Bezpośrednich dowodów takiego stanu rzeczy dostarczają nauki kognitywne. Z kolei bogata w cuda, fantastyczne zdarzenia oraz barwne, często całkowicie odrealnione postacie literatura science fiction udowadnia, jak bardzo kreatywny w działaniu jest ludzki mózg. Oczywiście w żadnym razie nie czyni to z nas istot uprzywilejowanych. Jesteśmy częścią wielkiego mechanizmu uniwersum. Stanowimy w nim drobną cząstkę, która nie znaczy więcej od kosmicznego pyłu. Po drugie, na miano człowieka zasługuje każdy organizm (biologiczny czy cybernetyczny), który wykazuje się inteligencja, abstrakcyjnym myśleniem oraz świadomością. Potwora Frankensteina, człowieka, robota, cyborga i system komputerowy łaczy przede wszystkim specyficzny program w postaci algorytmu postępowania. Jest to cecha obiektywna, obecna zarówno w świecie możliwym dzieł kultury, jak i w świecie rzeczywistym. W przypadku człowieka programem są dane zawarte w genie, utożsamianym z najmniejsza jednostką informacji systemu biologicznego. W przypadku grupy kulturowych praktyk czysto ludzkich możemy sprowadzić algorytm do roli, jaką w biologii pełni gen, nazywając go memem, czyli powielaną sekwencją postępowania w obrębie kultury ${ }^{137}$. Jest to oczywiście jedna $\mathrm{z}$ wielu propozycji badawczych. Człowiek, podobnie jak maszyna, kieruje się nieświadomym programem sterującym, o którym z reguły nie ma pojęcia. Ponadto podporządkowuje się schematom postępowania, wzorcom zachowań, decyzyjności rozmytej, obliczeniom oraz logice matematycznej za oraz przeciw. Pomimo powyższych faktów jesteśmy w pewien sposób uprzywilejowani, mając wyjątkowe prawo do egzekwowania naszej wolności - prawo buntu. Potrafimy bez problemu przeciwstawić się wynikom algorytmicznym, jeśli nastapi taka konieczność. W przypadku maszyn nie możemy mówić o memie kulturowym, lecz o dyrektywach. Zauważmy jednak, że my również bardzo często działamy zgodnie z wyznaczonymi odgórnie dyrektywami, zapominając o tzw. wolnej woli. W świecie realnym zgodność między świadomością ludzką a sztuczną inteligencją maszyn jest niemożliwa - przynajmniej na razie. W świecie fikcji możemy ją rozpatrywać na setki sposobów, czego skromnym przykładem jest niniejszy artykuł.

${ }^{137}$ Zob. R. Dawkins, Samolubny gen, przeł. M. Skoneczny, Warszawa 2012. 


\section{BIBLIOGRAFIA}

LITERATURA PODMIOTOWA

AI, sztuczna inteligencja [film], reż. S. Spielberg, scen. S. Spielberg, I. Watson, 2001.

Asimov I., Ja, robot, przeł. Z.A. Królicki, Poznań 2013.

Čapek K., R.U. R., Praha 2016.

Evil [film], scen. i reż. P.W.S. Anderson, 2002.

Ex Machina [film], scen. i reż. A. Garland, 2015.

Grabiński S., Demon ruchu, Warszawa-Kraków 1919.

Ja, robot [film], reż. A. Proyas, scen. A. Goldsman, J. Vintar, 2004.

Matrix [film], scen. i reż. L. Wachowski, L. Wachowski, 1999.

RoboCop [film], reż. J. Padilha, scen. J. Zetumer, 2014.

Terminator 2. Dzień sqdu [film], reż. J. Cameron, scen. J. Cameron, W. Wisher, 1991.

Terminator. Ocalenie [film], reż. J. McGinty Nichol, scen. J. Brancato, M. Ferris, 2009.

Tripplin T., Maskarada w obłokach, czyli podróż napowietrzna na Morze Pótnocne, Wilno 1856.

LITERATURA PRZEDMIOTOWA

1001 filmów, które musisz zobaczyć, red. S.J. Schneider, Warszawa 2004.

Agamben G., Profanacje, przeł. M. Kwaterko, Warszawa 2006.

Aldiss W., O pochodzeniu gatunków: Mary Shelley, [w:] M.W. Shelley, Frankenstein, przeł. H. Goldmann, Poznań 1989.

Atlas. The World's Most Dynamic Humanoid Robot, <https://www.bostondynamics.com/ atlas> [dostęp: 1.02.2020].

Ben-Ari M., Understanding Programming Languages, Chichester 1996.

Błaszczak M., Ptynność - od Heraklita do Baumana, „Przestrzenie Teorii” 2019, 31, s. $109-135$.

Brożek B., Hohol M., Umyst matematyczny, Kraków 2014.

Chalmers D., Świadomy umyst. W poszukiwaniu teorii fundamentalnej, przeł. M. Miłkowski, Warszawa 2010.

Clynes M.E., Kline N.S., Cyborgs and Space, „Astronautics” 1960, wrzesień.

Człowiek $w$ relacji do zwierzat, roślin i maszyn w kulturze, t. 2, Od humanizmu do posthumanizmu, red. J. Tymieniecka-Suchanek, Katowice 2014.

Darwin C., O pochodzeniu człowieka, przeł. S. Panek, Warszawa 1959.

Dawkins R., Samolubny gen, przeł. M. Skoneczny, Warszawa 2012.

Dennett D.C., Świadomość, przeł. E. Stokłosa, Kraków 2016.

Duch W., Fascynujacy świat komputerów, Poznań 1997.

Dunbar R., Nowa historia ewolucji człowieka, przeł. B. Kucharzyk, Kraków 2014.

Edelman G.M., Wider than the Sky: The Phenomenal Gift of Consciousness, New Haven 2004.

Fortey R., Życie. Nieautoryzowana biografia. Historia naturalna pierwszych czterech miliardów lat ̇̇ycia na Ziemi, przeł. M. Machalski, K. Sabath, Warszawa 1999.

Gajewska G., Arcy-nie-ludzkie. Przez science fiction do antropologii cyborgów, Poznań 2010 . 
Gemra A., Od gotycyzmu do horroru. Wilkołak, wampir i monstrum Frankensteina w wybranych utworach, Wrocław 2008.

Girard R., Kozioł ofiarny, przeł. M. Goszczyńska, Łódź 1991.

Godzimirski J., Lotnicze materiały konstrukcyjne, Warszawa 2008.

Grabowski M., Podziw i zdumienie w matematyce i fizyce, Warszawa 2009.

Haraway D., Manifest cyborgów: nauka, technika i feminizm socjalistycznych lat osiemdziesiatych, przeł. S. Królak, E. Majewska, „Przegląd Filozoficzno-Literacki” 2003, nr 1, s. 49-87.

Harnad S., Minds, Machines and Searle, „Journal of Experimental and Theoretical Artificial Intelligence” 1989, nr 1, s. 5-25.

Ilnicki R., Bóg cyborgów. Technika i transcendencja, Poznań 2011.

Jagielski J., Inżynieria wiedzy, Zielona Góra 2005.

James F., Field J., Frankenstein and the Spark of Being, „History Today” 1994, 449, s. 47-53.

Jurd R.D., Biologia zwierzat, przeł. A. Lesicki, K. Ziemnicki, Warszawa 2007.

Kartezjusz (R. Descartes), Rozprawa o metodzie właściwego kierowania rozumem i poszukiwania prawdy w naukach, przeł. T. Żeleński-Boy, Kraków 2002.

Kochanowska E., Romantyczna literatura wobec nauki. Henryk Ofterdingen Novalisa $i$ Genezis $z$ ducha Stowackiego, Wrocław 2002.

Kognitywizm w poetyce i stylistyce, red. G. Habrajska, J. Ślósarska, Kraków 2006.

Kombinezon „superżotnierza” staje się rzeczywistościa, <https://tech.wp.pl/kombinezon-superzolnierza-staje-sie-rzeczywistoscia-usa-juz-niebawem-uzbroi-nim-swoje-wojsko-6256653151475329a> [dostęp: 1.02.2020].

Kopaliński W., Stownik wyrazów obcych $i$ zwrotów obcojęzycznych z almanachem, Warszawa 2000.

Kubicki J., Historia największych odkryć anatomicznych ludzkiego ciała, „Puls Uczelni” 2015, (9) 1, s. 41-44.

La Mettrie J.O. de, Człowiek - maszyna, przeł. S. Rudniański, Warszawa 1984.

Lejwik H., Golem. Dramat w ośmiu obrazach, przeł. O. Mincer, Warszawa 2017.

Litmanowicz W., Giżycki J., Szachy od A do Z, t. 1, Warszawa 1986.

Lockheed Martin's HULC(TM) Robotic Exoskeleton Enters Biomechanical Testing At U.S. Army Natick Soldier Systems Center, <https://news.lockheedmartin.com/ 2011-06-30-Lockheed-Martins-HULC-TM-Robotic-Exoskeleton-Enters-Biomechanical-Testing-at-U-S-Army-Natick-Soldier-Systems-Center> [dostęp: 1.02.2020].

Łyczkowska K., Szarzyńska K., Mitologia Mezopotamii, Warszawa 1981.

Metodologiczne i teoretyczne problemy kognitywistyki, red. J. Woleński, A. Dąbrowski, Kraków 2014.

Nawrocki R., Zmierzch bezpieczeństwa oświeceniowych paradygmatów i jutrzenka stereotypu popkultury: gotycyzm i preromantyzm, „Świat i Słowo. Filologia, Nauki Społeczne, Filozofia, Teologia” 2013, 2 (21), s. 83-94.

Nervoplastica. Guy Ben-Ary „Sztuka bio-robotyczna i jej konteksty kulturowe”, red. R.W. Kluszczyński, Gdańsk 2015.

Problemy społeczne w grze politycznej, red. J. Królikowska, Warszawa 2006.

Profilowanie pojęć. Wybór prac, red. J. Bartmiński, Lublin 1993.

Radkowska-Walkowicz M., Od Golema do Terminatora. Wizerunki sztucznego człowieka w kulturze, Warszawa 2008. 
Raytheon XOS 2 Exoskeleton, Second-Generation Robotics Suit, <https://www.army-technology.com/projects/raytheon-xos-2-exoskeleton-us/> [dostęp: 1.02.2020].

Robot dostat obywatelstwo Arabii Saudyjskiej. Sophia „ma więcej zagwarantowanych praw niz kobiety" <https://www.forbes.pl/technologie/humanoidalny-robot-z-obywatelstwem-arabii-saudyjskiej/04wfw7n> [dostęp: 1.03.2020].

Searle J.R., Umyst, mózg i nauka, przeł. J. Bobryk, Warszawa 1995.

Searle J.R., Umyst. Krótkie wprowadzenie, przeł. J. Karłowski, Poznań 2010.

Stownik terminów z zakresu bezpieczeństwa narodowego, Akademia Obrony Narodowej, Warszawa 2008.

Stownik wyrazów obcych, red. I. Kamińska-Szmaj, Wrocław 2001.

Snelders H.A.M., Inorganic Natural Sciences 1797-1840: An Introductory Survey, „Studies in Romanticism" 1972, 11, s. 193-215.

Spitzer M., Jak uczy się mózg?, przeł. M. Guzowska-Dąbrowska, Warszawa 2007.

Stevenson R.L., Strange Case of Dr Jekyll and Mr Hyde, London 1886.

Stewart I., Matematyka życia, przeł. B. Bieniuk, E.L. Łokas, Warszawa 2014.

Strength To Go The Distance, <https://www.lockheedmartin.com/en-us/products/exoskeleton-technologies/military.html> [dostęp: 1.02.2020].

Sztuka i kultura robotów. Bill Vorn i jego histeryczne maszyny, red. R.W. Kluszczyński, B. Vorn, N. Gingras, D. Moulon, J. Walewska, P. Celiński, Gdańsk 2014.

Tegmark M., Nasz matematyczny Wszechświat. W poszukiwaniu prawdziwej natury rzeczywistości, przeł. B. Bieniuk, E.L. Łokas, Warszawa 2015.

The International Dictionary of Psychology, red. N.S. Sutherfand, New York 1989.

Trzecia kultura, red. J. Brockman, Warszawa 1996.

Turney J., Ślady Frankensteina. Nauka, genetyka i kultura masowa, przeł. M. Wiśniewska, Warszawa 2001.

Ville C.A., Biologia, przeł. H. Bielewska, T. Bilewicz-Pawińska, H. Gutowska, W. Kilarski, A. Makarewicz, W. Prażmo, Z. Stromenger, Warszawa 1978.

W strone trzeciej kultury. Koegzystencja sztuki, nauki i technologii, red. R.W. Kluszczyński, Warszawa 2011.

Wawrzecki J., Teoria maszyn i mechanizmów. Wstẹp do teorii mechanizmów przestrzennych, Łódź 2008.

Wielka encyklopedia PWN, red. J. Wojnowski, t. 6. Warszawa 2002.

Wielki stownik wyrazów obcych PWN, red. M. Bańko, Warszawa 2003.

Wydmuch M., Gra ze strachem. Fantastyka grozy, Warszawa 1975.

Wytrzymały Kevlar, czyli włókna aramidowe, <https://materialyinzynierskie.pl/wytrzymaly-kevlar-wlokna-aramidowe> [dostęp: 5.02.2020].

Żegleń U., Filozofia umystu, Toruń 2007. 